\title{
A antessala da demolição: revisitando o processo da montagem da Praça e Catedral da Sé de São Paulo, em primórdios do século XX'
}

The antechamber of the demolition: Revisiting the process of installation the Sé Square and Cathedral of São Paulo, in the early 20th century

https://doi.org/10.1590/1982-02672021v29e3

\author{
ALINE CANUTO DA SILVA² \\ https: / / orcid.org/0000-0003-1275-6051 \\ Universidade Federal de São Paulo / Guarulhos, SP, Brasil
}

RESUMO: Este artigo aborda um produto das relações e demandas em escala dos atores sociais, isto é, os indivíduos e as instituições nas esferas do público, eclesiástico e laico, envolvidas no processo da implantação da Praça e Catedral da Sé na antiga área central de São Paulo, entre os anos de 1903 e 1913. Colocando em tela o fenômeno da demolição no fazer urbano, buscamos compreender como para se realizar essa intervenção na paisagem urbana, com a feitura de novas estruturas urbanas como a praça e a catedral, demandou-se um circuito de propostas, definições e um aparelhamento que pensou, primeiramente, a feitura de uma cidade em demolição. Ou seja, um processo para o desmonte de estruturas antigas e preexistentes, que teve como resultado o desalojamento de inúmeros ocupantes da área-alvo. Desse modo, enfocamos uma arquitetura coletiva dos arranjos políitico, simbólico e de cifras em torno da obra, analisando o seu impacto em nível de uma rede reveladora da face social do processo, através dos nomes, dos acordos e negociações, tensões e contestações ao discurso acerca da realização da obra, que não se encontram assimiladas pela historiografia. Nesse sentido, agregamos uma documentação primária inédita, base da nossa reflexão, oriunda do Departamento de Desapropriações de São Paulo.

PALAVRAS-CHAVE: Praça. Catedral. Demolições. São Paulo. Sé. Desapropriação (fonte).

\begin{abstract}
1. Este artigo é parte (revista e adaptada) da monografia de graduação intitulada "Demolições no Complexo da Sé de São Paulo: construindo uma História Social das transformações espaciais paulistanas", desenvolvida sob orientação do prof. dr. Fernando Atique, e defendida em 2019. Foi resultado oriundo da pesquisa de Iniciação Científica, intitulada “"A Cidade Reconfigurada" - Investigação das demolições no entorno da Sé de São Paulo como suporte à história social das transformações espaciais", financiada pela Fundação de Amparo à Pesquisa do Estado de São Paulo (Fapesp) - Processo 2017/17774-0
\end{abstract}

2. Mestranda em História na Escola de Filosofia, Letras e Ciências Humanas, da Universidade Federal de São Paulo (EFLCH-Unifesp). Pesquisadora do Grupo de Pesquisa Cidade, Arquitetura e Preservação em Perspectiva Histórica (CAPPH), sediado na mesma instituição. Possui graduação em História pela Universidade Federal de São Paulo (Unifesp). E-mail: <alinecanuto7@hotmail.com>. 
ABSTRACT: This article addresses a product of the relationships and demands in scale of the social actors, that is, the individuals and institutions in the public, ecclesiastical and secular spheres, involved in the process of the implantation of the Sé Square and Cathedral in the old central area of São Paulo, between the years 1903 and 1913. Placing on canvas the phenomenon of demolition in the urban making, we sought to understand how to carry out this intervention in the urban landscape, with the making of new urban structures such as the square and the cathedral, demanded a circuit of proposals, definitions and an apparatus that thought, first, the making of a city in demolition. That is, a process for the dismantling of old and preexisting structures, which resulted in the displacement of numerous occupants of the target area. In this way, we focus on a collective architecture of political, symbolic and cipher arrangements around the work, analyzing its impact at the level of a network revealing the social face of the process, through the names, agreements and negotiations, tensions and contestations to the discourse about the realization of the work, which are not assimilated by historiography. In this sense, we have added an unprecedented primary documentation, the basis of our reflection, from the Department of Expropriations of São Paulo.

KEYWORDS: Square. Cathedral. Demolitions. São Paulo. Sé. Expropriation (source). 
A conformação da Praça da Sé passou a constar nos mapas da antiga área central de São Paulo já na década de 1910. Esta Praça adveio de uma intenção religiosa, e também pública, que seria a de servir tanto como adro da nova catedral da cidade quanto na reorganização dos territórios simbólicos do poder urbano. Representando a instituição religiosa efetivamente no debate urbano, atentando para o movimento que durante as duas primeiras décadas do século XX voltou o foco sobre a área do Antigo Centro, a idealização da Praça foi marcada por demandas que passaram por um ator social determinante no processo: Dom Duarte Leopoldo e Silva (1867-1938). Nascido em Taubaté, cidade do Vale do Paraíba Paulista, Dom Duarte foi o primeiro arcebispo de São Paulo. A bula papal Dicecesium Nimiam Amplitudinem criou em 7 de junho de 1908 a Província Eclesiástica de São Paulo. Com a criação da arquidiocese, nasceu o arcebispo. ${ }^{3}$ Esse nascimento veio a coroar um processo de aproximação entre as elites econômicas e a lgreja Católica, como pontuou Cristina de Toledo Romano (2008). Dom Duarte era ligado ao processo de romanização da igreja, o que the garantia uma posição amparada por Roma e sedutora à elite paulista, que via nas ações do religioso a possibilidade de elitizar e ordenar a fé e, consequentemente, a cidade.

Assim, a pedra fundamental da catedral foi oficialmente lançada por seu articulador maior perante a sociedade paulistana no ano de 1913. Este passou a buscar o lugar-gênese do Largo da Sé colonial para remontálo, como notou Rebeca Grillo de Sousa (2016), à tradição de seu grupo originário naquele espaço urbano. ${ }^{4}$ Na definição de Maurício de Aquino (2012), houve uma refundação simbólica da área do largo colonial, com o advento da praça revestida do mito moderno pelas mãos do arcebispo. 5 Dom Duarte passou a dirigir os católicos na capital paulista, e ampliou o processo de articulação da burguesia junto à lgreja, de forma a garantir não apenas a recuperação da ideia de nova sede religiosa para São Paulo, mas também da construção de uma catedral metropolitana, efetivamente. Contudo, foi o logradouro revestido de um caráter ambíguo, pois respaldou a municipalidade que o via como Praça Municipal, cogitada como abrigo para as sedes da Câmara Municipal e da Prefeitura (nunca instaladas). Houve então uma ideia de centro cívico para São Paulo. Curiosamente, incorporando também a catedral que representava a igreja, um poder apartado do Estado desde a instauração da República, mas que se alinhava tanto às forças políticas quanto aos edifícios administrativos na configuração espacial daquela área. Ao mesmo tempo, a montagem da Praça da Sé nos anos de 1910 esteve implicada na abertura de uma espécie de esplanada, que levou não só ao desaparecimento da antiga conformação do Largo da Sé como à própria erradicação da Antiga Matriz da Sé e da igreja de S. Pedro. Mas, para além dos dois templos, existiam muitas outras edificações e pessoas, em geral, veladas nas histórias da cidade.
3. "Archbishop Duarte Leopoldo e Silva." Catholic Heritage. Disponível em: $<$ https://bit.ly/3gGv8kd>. Acesso em 18 de mar de 2018.

4. Sousa (2016, p. 133).

5. Aquino (2012, p. 149) 
6. Novo (2017, p. 154).

7. Cerasoli (1998, p. 5).

8. Atique (2016, p. 160$)$.

9. Tomamos em perspectiva a contribuição do historiador inglês Edward Palmer Thompson (2004, p. 14) para uma leitura historiográfica do fenômeno histórico urbano onde se percorre e redimensiona os lugares dos indivíduos, em suas dimensões experienciais e culturais, de maneira a reconstituir seus pontos de vista, práticas e modos de vida, em termos de uma história social dos eventos no processo de urbanização. O que nos leva a buscar perscrutar assim também, dentre os múltiplos grupos sociais envolvidos, as interações oriundas daqueles os quais Thompson cunhou como as classes subalternas, numa história de baixo para cima. Nos propomos então a observar em nossa pesquisa ampla, o aporte de registros possíveis para se dimensionar, para além das camadas elitizadas dos proprietários, as manifestações insubordinadas e insurgentes de uma cidade habitada, uma cidade dos usos daqueles populares (Id., 2005, p. 19) como da camada dos ocupantes que, junto com as estruturas físicas, foram desaparecidos desta antiga área central com as suas funções e costumes urbanos, que imprimiam uma outra dinâmica de circulação de pessoas naquela configuração de quadras que foram removidas. $\mathrm{Cu}$ mpre-nos assinalar que este ponto da discussão ganha foco exploratório e suporte de fontes primárias indiciárias para a leitura thompsoniana que nos ancora, no Capítulo 2 do nosso trabalho monográfico de pesquisa.
Neste artigo analisamos então a conformação da Praça da Sé, para além de uma questão formal, como uma questão de fundo político. Valendo-nos das metáforas que Leonardo Novo (2017) e Josianne Cerasoli (1998) cunharam, as demolições efetuadas nesta área central de São Paulo podem ser vistas como elementos de engenharias de poder e de arquiteturas políticas. Este artigo então pretende contribuir para a compreensão das mudanças profundas que a cidade passou ao longo do século XX, sobretudo porque aquilo que se chama na história da cidade de Triângulo Histórico teve o seu centro geométrico alterado profundamente ao longo dos anos. Assim, permite esse artigo também uma contribuição a uma história daquilo que São Paulo destruiu, ajudando a desmontar e a desnaturalizar um processo de fruição da cidade, que subjaz num imaginário de metropolização e espaços amplos em pleno centro da cidade. O que se propõe aqui, ao invés disso, é mostrar o processo de transformação da cidade, ou seja, uma história de um processo de mudança. Quando analisamos transformações espaciais, devemos notar quais personagens estavam inseridos nessas áreas-alvo de modificação. Tentar identificá-los permite a construção de uma história social que revela os conflitos, desmistifica o papel transformador do Estado, humaniza os técnicos e dá voz àqueles que foram tratados, quando muito, como dados estatísticos. Como tem mostrado Fernando Atique (2016),

sendo a cidade também um universo de pedras, o desaparecimento de edificações mostra que a memória é apenas uma das dimensões do campo do patrimônio, e como tal, fenece e não substitui a experiência urbana como deflagradora e constituinte da mesma. ${ }^{8}$

Esse alerta mostra que a história das práticas de planejamento urbano, se for além da ideia e dos intelectuais daquele campo, trazendo as repercussões sociais e permitindo a leitura dos conflitos, garantirá uma aproximação Thompsoniana à história da cidade. ${ }^{9} \mathrm{~A}$ história da (não) preservação, dessa maneira, serve de janela para a compreensão de tantos personagens ledificados e humanos) que ficaram alijados de registro. 


\section{A PREPARAÇÃO DO "TERRENO": A CAMPANHA DE DEMOLIÇÃO NO CIRCUITO ${ }^{\circ}$ DA IMPRENSA}

A proposta da remoção da Antiga Matriz da Sé para a sua substituição passou pela mobilização do circuito da imprensa, através de seu articulador maior no processo, Dom Duarte. Inaugurando essa defesa em artigo intitulado "As Nossas Igrejas", publicado no Jornal do Commercio de S. Paulo em 11 de março de 1906, apelava à sociedade paulistana, uma unanimidade católica no seu discurso, listando em específico dois setores deste corpo social, que deveriam auxiliar a Igreja na criação do progresso: a administração pública e os particulares, vistos como aqueles grupos de promotores do projeto de transformação pelo qual passava a cidade. Dom Duarte explicitava no seu discurso a "picareta demolidora nas mais vetustas construcções da antiga Paulicéia", como uma solução em chave positiva e cabível para a Antiga Matriz da Sé:

\footnotetext{
A egreja da Sé não é susceptivel a conserto, ou de reforma que a torne um templo condigno do seu destino, isto é, uma bella e grande cathedral, como deve ser a sede apostolica deste bispado.

$[\ldots]$

O seu aspecto exterior nada tem de notavel a não ser que - é est vieux. $\bigcirc$ frontespicio não se reveste de nenhuma nobreza ou magestade; ao contrario, é commum, mauco, por ter somente uma torre lateral, e acaçapado. Adianta desgraciosamente até ao meio da praça o seu corpo desgracioso e pesado. ${ }^{11}$
}

Na linguagem de Dom Duarte, a Antiga Matriz da Sé era uma catástrofe urbana, em termos compositivos e tectônicos. Essa ideia era antiga no ambiente da lgreja, e mesmo na imprensa. Em um artigo no jornal do Correio Paulistano em 19 de agosto de 1904, já evocava no processo uma reconstrução total da cidade, e atacava a igreja de S. Pedro, que junto com a Antiga Matriz da Sé, conformava - Largo no Centro da cidade. Defendia ser o Largo da Sé onde "precisamente mais se tem feito sentir o obsoleto [...] dos passados tempos". Ainda, no artigo, explicitamente dizia ser importante desapropriar propriedades da área e, em especial, demolir a lgreja de S. Pedro, pois assim,

completar-se-ia a excellente idea, ampliando-se tambem o largo da Sé, pequeno, apertado, insufficiente para as necessidades de espaço e curso [...]. E para isso bastará estender a desapropriação, ainda que gradual e parcelladamente, áquella egreja e aos sobrados vizinhos.
10. Utilizamos o termo "circuito", tal como propôs Fernando Atique (2016, p. 153), para associar os grupos, instrumentos e práticas que se coadunam e correspondem àquilo que chamou de circuito social das demolições, em que, assim como as construções, obedece igualmente aos trâmites da "idealização, da produção, da construção, da circulação", preconizando, portanto, uma obra coletiva do esfacelamento.

11. "As nossas egrejas." Commercio de S. Paulo. 11/03/1906. 
12. "Actualidades." Commercio de S. Paulo. 19/08/1904.

13. Pinto (1900, p. 2).

14. Frehse (2001, p. 170).

$[\ldots]$

A egreja, [...] está de ha muito sem culto religioso contínuo, que alli justifique a sua indispensavel permanencia; tanto mais que qualquer falta a esse respeito, quando se dêsse, seria satisfactoriamente supprida, como já acontece, com os offícios da Cathedral, preferida sempre para taes misteres. ${ }^{12}$

Inaugurando no debate público a ideia da demolição da igreja de S. Pedro, a sua campanha pela demolição, porém, veio revestida de ambiguidade. Não bastava demolir a Antiga Matriz da Sé. Era necessário também derrubar a igreja de S. Pedro, vista por diversos atores sociais, inclusive memorialistas como Alfredo Moreira Pinto (1900), carioca que retornou a São Paulo após 30 anos afastado, como obsoleta:

\footnotetext{
Está situada no largo da Sé e ao lado da Cathedral.

Suas paredes ennegrecidas dão-the um aspecto lúgubre.

Tem duas torres, cinco janellas e três portas.

O interior é paupérrimo. ${ }^{13}$
}

\section{OS PRIMEIROS DESMONTES NA ÁREA DA SÉ, JÁ NA DÉCADA DE 1900}

Perscrutando a imprensa sobre os movimentos da lgreja na busca de sua nova sede, foi notada a emergência de uma nova pauta, que era a da possibilidade de desapropriações. Essas informações de caráter desapropriatório colaboram para a ressignificação de uma cronologia associada a essa área central da cidade e para uma historicização da mudança, como propôs Frahya Frehse (200 1), entendendo a mudança da configuração urbana como um processo. ${ }^{14}$ Nestes termos, ainda o artigo do jornal apontava a demolição acontecendo na quadra adjacente à referida igreja do Largo da Sé já em 1903. Dar início às demolições cumpria efetivamente uma função, a de mostrar como a liberação de espaços naquela área colonial traria o progresso de forma irrefutável:

Para alargar a rua da Fundição, foram já desapropriados e demolidos os predios que ficavam na linha lateral da egreja de S. Pedro, e, em seguimento desse acertado plano, a Camara Municipal resolveu prolongar até áquella a rua do Quartel, cortando a travessa da Sé e os fundos da dita egreja e da casa vizinha desta, na esquina. 
As casas vizinhas, velhas, estragadissimas, pouco mais excederão em estimativa ao valor do terreno.

Adquiril-as desde logo, nessas condições, uma vez que já se vae pagar, para demolir, os fundos necessarios ao prolongamento da rua do Quartel, não ha de ser por certo um tão pesado accrescimo de despesa, para as forças financeiras do municipio. Aliás, não se deve esquecer, por outro lado, as enormes vantagens que a medida traz á população, compensando mesmo quaesquer sacrificios do momento. ${ }^{15}$

Neste ponto, as duas plantas desapropriatórias oriundas do Departamento de Desapropriações, da quadra que originalmente conformava o Largo da Sé (Figura 1 e 2), grafam o contexto em que os prédios adjacentes ${ }^{16}$ à Igreja de S. Pedro foram subtraídos. Os selos deram registro às expropriações de dois proprietários particulares, corroborando a ocorrência entre 1902 e 1903 da desapropriação, em uma operação de permuta justificada para alinhamento da rua da Fundição:

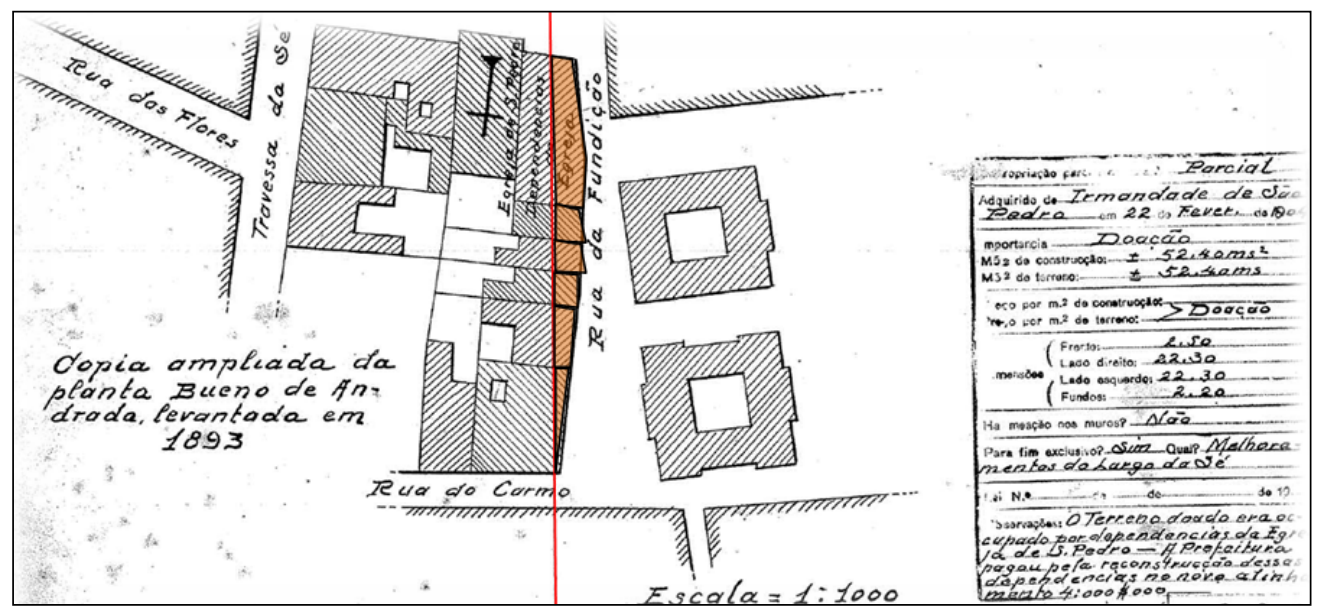

Figura 1 - Levantamento da área demolida em conjunto com a lgreja de S. Pedro, para a feitura do alinhamento destacado em laranja, no Largo da Sé. Fonte: Planta 64_B 1_DESAP [Lei 1409].

Não obstante é visto que os valores pagos como desapropriação foram elevados. Ao confrontarmos as cifras desse ator, da municipalidade que dispendia do Tesouro com a expropriação-demolição, um elemento pontual de comparação de grandeza monetária, mas que nos dá uma dimensão em relação aos valores elevados em contos de réis aparecendo no caso-a-caso da operação com os particulares, são os salários de uma parcela dos múltiplos atores sociais que se achavam em segmentos da burocracia dos setores médios urbanos no transcurso do processo, em suas ocupações e saberes manuais e especializados, mediados no lugar do público, e que o Correio Paulistano publicou (Tabela 1).
15. Actualidades. Commercio
de S. Paulo, 19 ago. 1904.

16. Sousa (2016, p. 133) recuperou uma informação de haver cortiços, casas de prostituição, coexistindo próximos da matriz, ali no Largo da Sé, bem como uma população negra, que foi desarticulada pelas intervenções do Estado - reforçando o expediente higienista da demolição. 


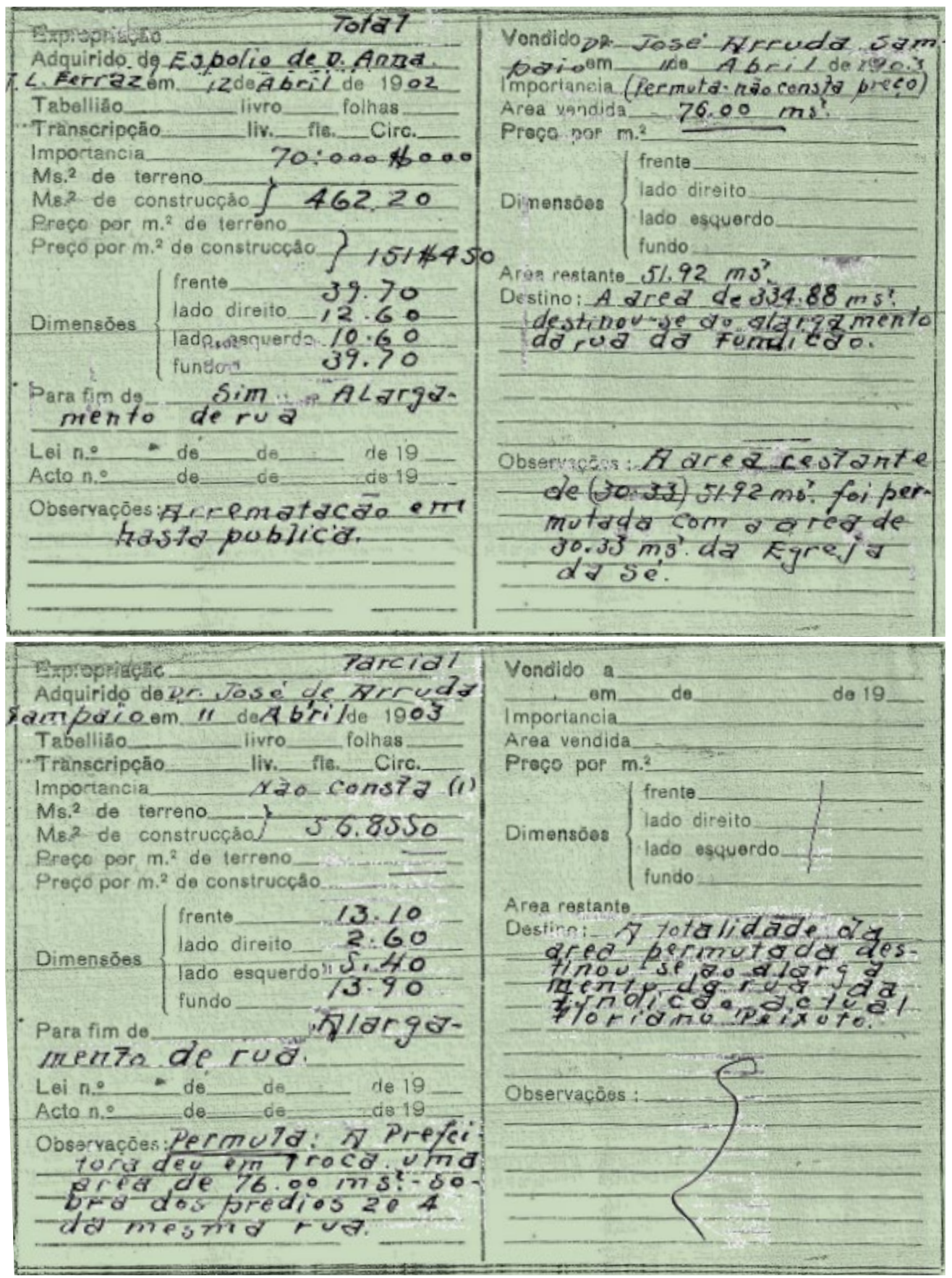

Figura 2 - Selos descritivos da expropriação da área demolida em conjunto com a lgreja de S. Pedro, no Largo da Sé. Fonte: Planta 41_B1_DESAP [Lei 1409]. 


\begin{tabular}{|c|c|c|c|}
\hline Classe Social & \multicolumn{2}{|c|}{ Profissões } & Salário Mensal \\
\hline \multirow{8}{*}{$\begin{array}{c}\text { Setores médios } \\
\text { urbanos }\end{array}$} & \multirow{8}{*}{ Empregados públicos } & Varredores & $100 \$ 000$ \\
\hline & & $\begin{array}{l}\text { Coveiros dos cemité- } \\
\text { rios da Consolação, } \\
\text { Vila Mariana, Penha } \\
\text { de França e Santana }\end{array}$ & $120 \$ 000$ \\
\hline & & $\begin{array}{l}\text { Maquinistas do Mata- } \\
\text { douro }\end{array}$ & $160 \$ 000$ \\
\hline & & $\begin{array}{l}\text { Pesadores e carimba- } \\
\text { dores do Matadouro }\end{array}$ & $180 \$ 000$ \\
\hline & & $\begin{array}{l}\text { Desenhistas da Direto- } \\
\text { ria de Obras e Viação }\end{array}$ & $450 \$ 000$ \\
\hline & & $\begin{array}{l}\text { Engenheiros e topó- } \\
\text { grafos da Diretoria de } \\
\text { Obras e Viação }\end{array}$ & $900 \$ 000$ \\
\hline & & $\begin{array}{c}\text { Diretores da Direto- } \\
\text { ria do Patrimônio, } \\
\text { Estatística e Arquivo } \\
\text { Municipal }\end{array}$ & 1:000\$000 \\
\hline & & $\begin{array}{l}\text { Diretores da Diretoria } \\
\text { de Obras e Viação }\end{array}$ & $1: 500 \$ 000$ \\
\hline
\end{tabular}

Tabela 1 - Salários de setores médios urbanos (1909-1913). Fonte: Secretaria Geral da Prefeitura de S. Paulo (1909). In: Correio Paulistano. Acto N.573 de 16 de abril de 1913 (reorganiza as repartições da Prefeitura). 17 abr. 1913.

Comparando as áreas dos imóveis com os valores concedidos pela municipalidade aos particulares, é visto que a proprietária Anna J. L. Ferraz recebeu o montante de 70:000\$000 por um imóvel de 334,88 m², enquanto o proprietário José de Arruda Sampaio levou uma soma de 56:855\$000 pela construção de apenas $76,00 \mathrm{~m}^{2}$. Já a planta também descreve uma operação onde a Irmandade de S. Pedro, por volta de 1905, cedeu como doação uma parte de seu terreno à municipalidade para um alinhamento. No entanto, o selo da planta mostra que a Irmandade, para fins da "reconstrucção dessas dependencias no novo alinhamento", uma vez que o "terreno doado era ocupado por dependencias da egreja", recebeu da municipalidade uma cifra de 4:000\$000. A imprensa, curiosamente, não mostrou esses descompassos no processo de demolição no perímetro. Mas uma nota publicada pelo jornal do Correio Paulistano em 13 de setembro de 1904 nos permite entender que tanto a campanha de demolição quanto a negociação que desmontou e pretendeu reconstruir a igreja de S. Pedro, sofreram reveses. Durante as demoliç̃es contíguas ao templo religioso para a implantação do novo alinhamento, a lgreja 
17. Desmoronamento. Correio Paulistano, 13 set. 1904.

18. Sousa (2016, p. 133).

19. Josianne Cerasoli (2004, p.3-4) introduz esta leitura compartilhada em um movimento historiográfico recente, preocupado em antever a transformação da cidade, não numa perspectiva linear e monolítica, mas como um processo, nas "transições percebidas na experiência urbana - reais, planejadas ou desejadas", entendendo logo cidade como espaço de "negociações e embates".

20. Mattos (1992, p. 39). foi modificada em seus alicerces, em virtude das obras de alargamento da rua da Fundição, sendo completamente reconstruida uma parede lateral e executadas outras obras de segurança.

Hontem, [...] a parede dos fundos daquelle templo, que mede nove metros, mais ou menos, de altura, por quinze de comprimento, veiu por terra, para dentro da egreja, destruindo completamente um altar e damnificando outros $[\ldots]^{17}$

\section{A COSTURA POLÍTICA PARA A FEITURA DA PRAÇA E CATEDRAL}

Rebeca Grilo de Sousa $(2016)^{18}$ foi perspicaz na síntese de que o caso do desmonte efetuado na Sé a partir de 1910, não se denota a priori por uma demolição de ruínas, mas por uma demolição por rearranjos ou acordos. ${ }^{19}$ Alguns aspectos pouco conhecidos do processo paulistano de demolição do Largo da Sé foram trazidos pelo Monsenhor Sylvio de Moraes Mattos (1992). Este amealhou, com o seu acesso tido a partir de dentro da instituição, pelos arquivos e memórias do circuito eclesiástico, que na proposta inicial "[f]icaria, pois, a nova catedral no local da velha Sé, sendo apenas a construção recuada em seu alinhamento para coincidir com o alinhamento da Travessa da Sé." ${ }^{20}$ No entrecruzamento das versões e dos contornos cogitados sobre a proposta de localização da catedral, soma-se também a documentação burocrática da desapropriação sob a Lei n 1305 de 11 de abril de 1910, que incorpora à rede dos agentes um outro ator social e demandante do circuito político, revelado pela atuação de destaque no processo. Como prefeito, Antonio Prado atuou de maneira determinante na concretização do desmonte da área da Sé, numa interlocução próxima com o artífice pela lgreja, Dom Duarte. Em um primeiro documento manuscrito redigido em 25 de março de 1909, o secretário representante do arcebispo propunha diretamente ao prefeito uma permuta, a cuja tratativa era explicitada a convergência entre a municipalidade e a igreja. Noutras palavras, era o elemento especulativo aproximando uma esfera particular (a elite eclesiástica) e pública (a municipalidade) no processo. Era buscado, pois, um consenso tanto na definição da área que deveria entrar em tratativa de desapropriação quanto nas cifras de fundo indenizatório, que a igreja especulava levar com o acordo:

Exmo. Sr. Conselheiro Antonio Prado.

\section{$[\ldots]$}

[...] pelo Arcebispo Metropolitano [...] as bases de um accôrdo para a permuta dos terrenos municipaes e outros com immoveis pertencentes à Mitra [...] as clausulas em que julgo poder realisar-se o negocio, com vantagem para ambas as partes. 
Para que a nova Cathedral seja levantada no perimetro designado na planta annexa e ao mesmo tempo o patio da Sé e as ruas adjacentes sejam alargadas na medida indicada na mesma - a Prefeitura terá de concorrer com 1373 metros quadrados, representados em terrenos publicos e immoveis dependentes de desapropriação, ao passo que receberá da Mitra 1246 metros quadrados, representados em terrenos ora occupados pela velha Cathedral e predios adjacentes.

Por ahi se vê que as areas a permutarem-se são sensivelmente iguaes, havendo apenas a differença de 127 metros quadrados, a mais nova Cathedral - uma boa parte 1365 metros quadrados) está representada pelo leito da rua Santa Thereza, onde não existem bemfeitorias, além do calçamento.

Nestas condições, é evidente que a base justa, equitativa, do negócio está na permuta das duas areas - recebendo a Mitra da Prefeitura uma indenisação pecuniaria correspondente á differença do valor dos immoveis em transacção.

Acredito que o Sr. Arcebispo se contentará com uma indenisação relativamente insignificante, apenas de 60:000\$000 de réis, e pagável de modo muito facil - em cinco prestações annuais de 12:000\$000 de réis cada uma [...].

[...] é pensamento do Sr. Arcebispo começar a construcção da nova Cathedral na parte que não affecta a egreja atual. ${ }^{21}$

Colocando em termos o itinerário da demanda que a tratativa do arcebispo exigia, ficava implícita a colaboração de um engenheiro, não identificado na documentação, para estudar a área-alvo. Dessa forma, por meio da operacionalização da cartografia, isto é, de uma planta com base cadastral, todos os lotes do entorno e da adjacência foram levantados, com a Antiga Matriz no Largo da Sé sendo o parâmetro comparativo. Assim, planta em questão (Figura 3) dá uma dimensão da área-gênese do desmonte, das primeiras demolições que iriam transformar a fisionomia da antiga área central da cidade. Compreendida entre o Largo da Sé e a Praça João Mendes, no miolo da geometria do Triângulo central, essa faixa notavelmente extensa abrigava um total de 61 lotes distribuídos nas duas quadras conformadas pelas ruas Capitão Salomão (26 lotes), Travessa da Esperança (3 lotes), Marechal Deodoro ( 15 lotes) e Santa Teresa ( 17 lotes). Ao Norte, existia uma terceira quadra exatamente no Largo da Sé, onde se situava a Antiga Matriz.

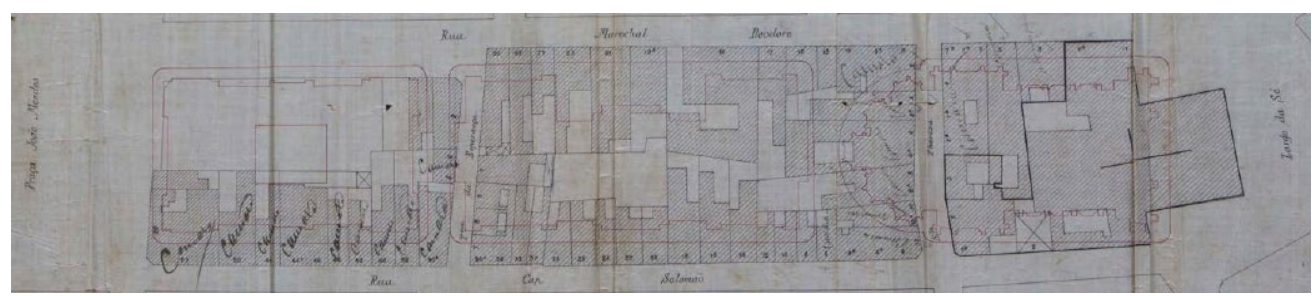

21. Avulso. 25/04/1909. "Lei n.1305". Prefeitura do Município de S. Paulo. Diretoria do Protocolo de Arquivo $\mathrm{N}^{\circ}$. Série Legislação. São Paulo: AHM.

Figura 3 - Levantamento cadastral e projetação em área demolida para a conformação da Catedral e Praça da Sé. Fonte: Lei - Planta $n^{\circ}$ 1305/1910. "Série Legislação". AHM. 
A lgreja, ao demandar de um engenheiro o estudo da área pretendida, trouxe vários lotes discriminados para o acordo, dos quais, aqueles pertencentes à particulares. Em realidade, tratava-se de uma planta-projeto, em que o trabalho técnico que a igreja demandou já era visível, uma vez que havia a projeção com destaque em vermelho do perímetro do novo templo neogótico, acima das quadras discriminadas na planta. Entretanto, se insinuava graficamente o projeto em mesma posição e área ocupada pela Antiga Matriz no Largo da Sé. Nesse sentido, era significativa a deixa do arcebispo, através de seu emissário, para "começar a construcção da nova Cathedral na parte que não affeta a egreja atual". Assim, forjava-se no discurso da transformação urbana, a produção da cidade a partir de um grupo, a igreja, que mobilizava a cartografia 22 para manipular essa relação de valores que operaria o desmonte na área. Valores que, evidentemente, não se confirmavam, uma vez quando a área arrasada não correspondeu ao que ali se projetou, pois abarcou uma área notoriamente maior. Logo, envolveu valores maiores para que fosse erguida no ponto oposto ao Sul do Largo, de costas para a Praça João Mendes.

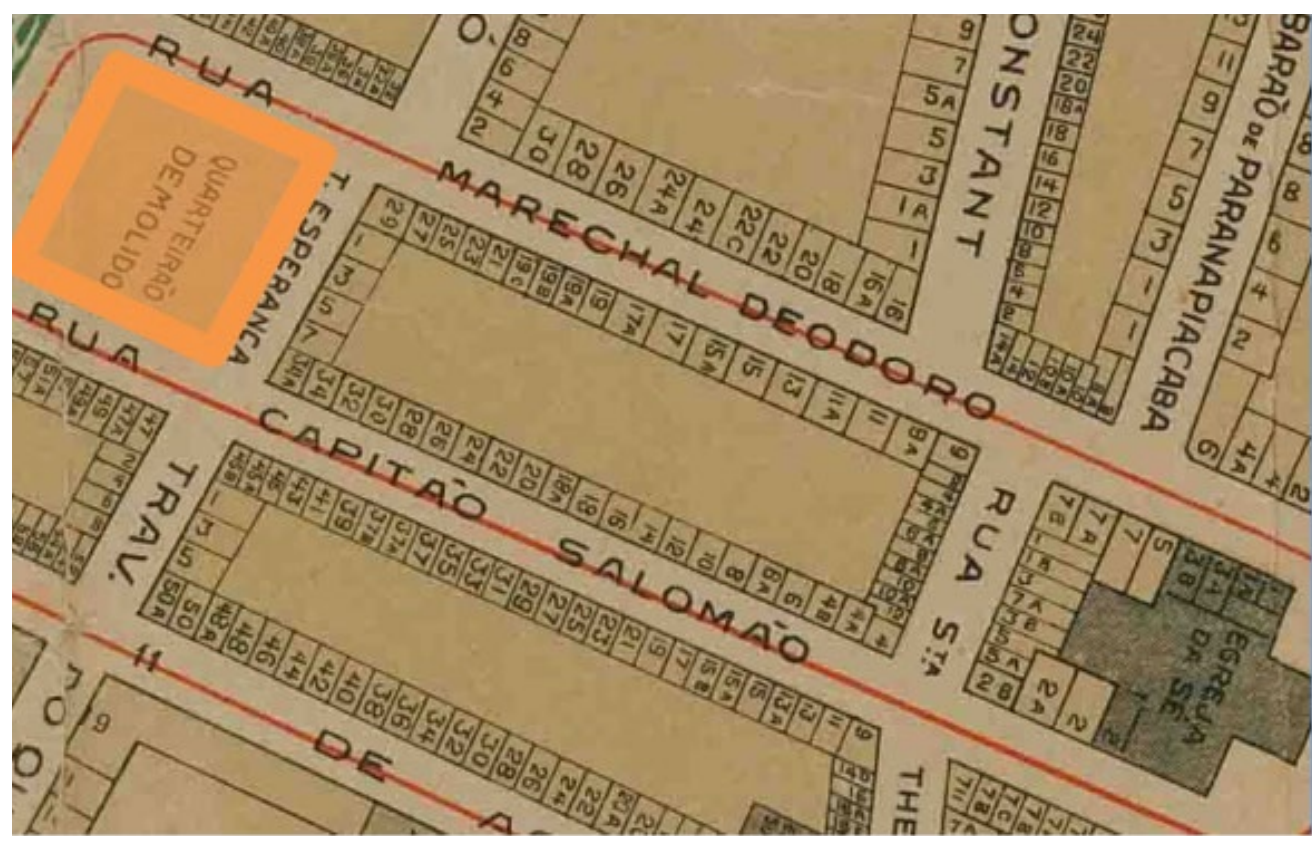

Figura 4 - Recorte de planta cadastral produzida no contexto das obras de demolição no miolo da Sé, trazendo nela inscrito, como destacado em laranja, a ordem do primeiro "quarteirão demolido", com face para a Praça João Mendes. Fonte: "Planta Cadastral e Comercial da Cidade de São Paulo" (1911). Editores: Thomas \& Cia, APESP. 
Entretanto, concorria para este processo de escolha do local para o desmonte uma obra em paralelo sobre uma mesma temporalidade: a construção de um Centro Cívico. A começar pelo novo Paço Municipal. Observando essa possível operação espacial, uma primeira evidência se acha na planta comercial de autoria de Thomas e Cia., produzida em 1911 (Figura 4). De acordo com o que demarcava a planta, naquela altura já se achava demolida toda a quadra do ponto da Praça João Mendes. Uma nota publicada no jornal d'O Estado de S. Paulo em 5 de julho de 1911 confirmava o processo da demolição acontecendo. Segundo o jornal, havia recomeçado as obras de demolição das "casas já desapropriadas da rua Capitão Salomão, no trecho da travessa da Esperança para baixo", estando estas obras "levadas a effeito para o alargamento daquella via publica." ${ }^{23} \mathrm{Ou}$ seja, as demolições começaram por aquele ponto, contrariando o termo das tratativas de abertura de clareira na área que supostamente estaria destinada à construção da catedral (no Largo da Sé).

Aparentemente também, o local aberto tampouco foi investido de consenso para a montagem do Paço, tendo em vista os debates na esfera municipal a partir de 1909. Na sessão de 5 de junho de 1910, o vereador Sampaio Vianna indicava no seu Requerimento a existência de um jogo de tensões dentro da esfera municipal, entre os atores legisladores e o ator-executivo, o prefeito. O vereador lembrava, até onde era sabido, que a faixa de terreno defronte a Praça João Mendes estava "destinada, ha muitos annos, á construcção do Paço Municipal". Para este fim, havia a Câmara levantado um empréstimo externo, para desapropriações que já ocorriam. Todavia, o mesmo reclamava que "sem que a Câmara tenha tido conhecimento de ser adiada a construcção", tampouco o conhecimento sobre o prefeito tê-lo arrendado ou o cedido em concorrência pública, foi construído "um grande barracão nos terrenos do antigo theatro S. José", não se tratando de uma construção "com caracter provisorio, porque as obras que se estão fazendo denotam o intuito de permanência." 24 Sua fala evidenciava ainda um processo de disputas na produção social daquele lugar. Elizabeth Miyazaki (1979) deu mostras de um viver urbano que resistia e formatava ali um claro atrito sobre o decurso da obra, ao chegar ao registro fotográfico de um impresso à mesma época, em 1910 (Figura 5):

O terreno murado à esquerda é hoje ocupado pela parte posterior da Catedral. Na época em que foi tirada a fotografia, nele estava instalado um circo. Os circos, então muito frequentes, representavam a herança de notável tradição e importante divertimento para a população. Além dos espetáculos de habilidade e do palhaço, havia representações teatrais, geralmente comédias. ${ }^{25}$
23. O Estado de S. Paulo. 05/07/1911.

24. Requerimento N.9 de 1909. Correio Paulistano, 5 jun. 1910.

25. Miyazaki (1979, p. 11). 
26. D'Elboux (2015, p. 470).

27. Ibid. (p. 549).

28. O Estado de S. Paulo, 9 jul. 1911.

29. Ibid. (p. 7).

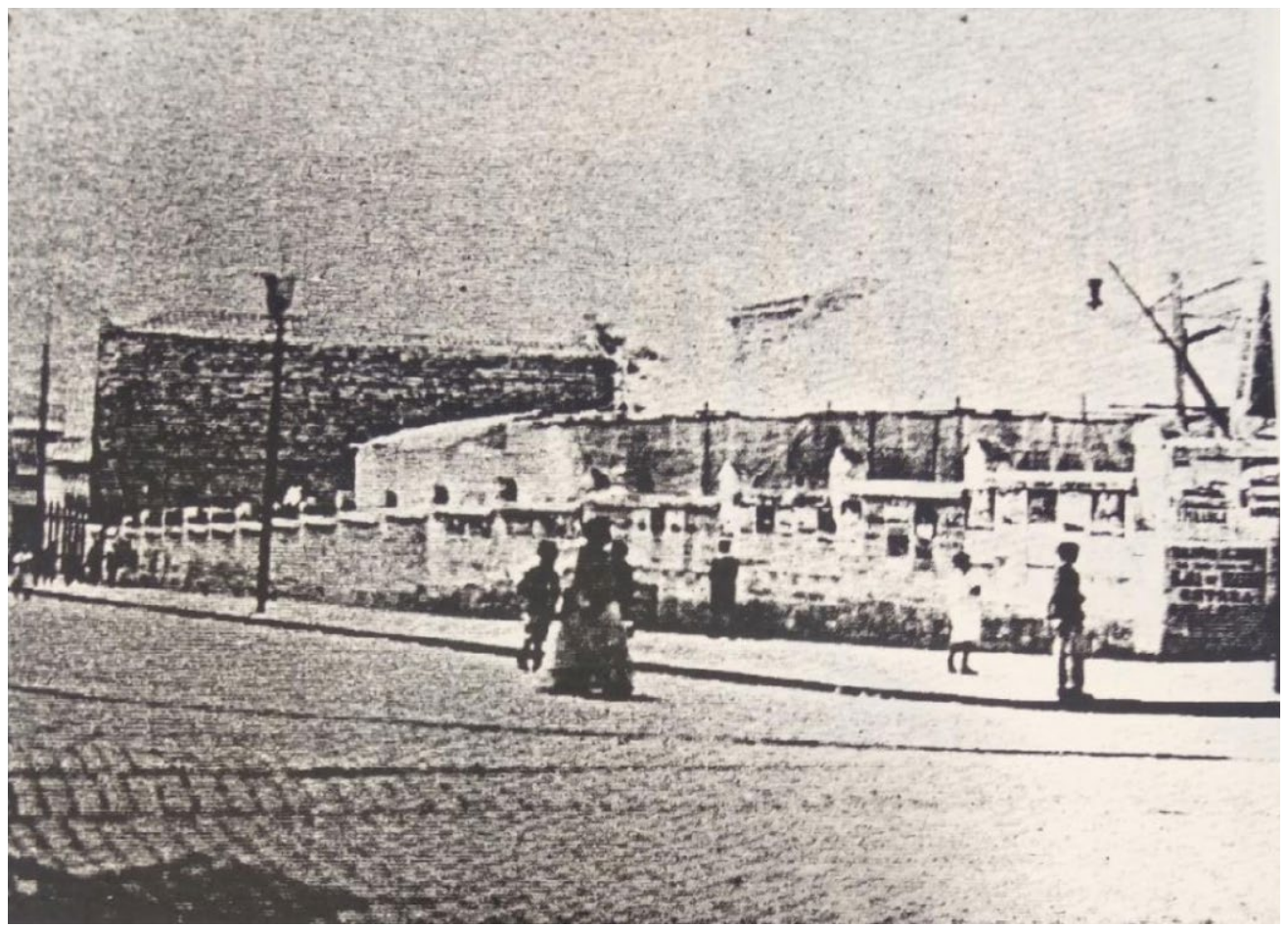

Figura 5 - Memória da Sé, 1910. Fonte: Miyazaki (1979, p. 111$).$

\section{A IDEIA DO "CENTRO CÍVICO" NA RECONFIGURAÇÃO DO ANTIGO CENTRO}

Roseli D'Elboux (2015) apresentou em sua tese uma outra face da ideia de um Centro Cívico na Sé, ao analisar a presença do arquiteto francês Joseph Bouvard, quem teve seu papel no plano de sua projetação. O que se chamava de centro cívico, de fato, traduzia simbolicamente uma vontade de junção dos edifícios públicos, conciliando as esferas municipal, estadual e eclesiástica. ${ }^{26}$ Uma coluna dedicada em noticiar o Paço Municipal, publicada no jornal d' $O$ Estado de S. Paulo em 9 de julho de 1911, amarrava a síntese da retórica pactuada de centro simbólico, ${ }^{27}$ que sobreporia às mais antigas quadras da Sé pela área de 3139 metros quadrados, dominando-a em face de um "grupo de grandes edificios que vão constituir a acropole paulista: a Cathedral, o Forum, o Congresso Estadual." ${ }^{28}$ Por intermédio do ator e braço do saber técnico municipal, Victor Freire, Bouvard exemplificava mais uma vez a rede de colaboração que mobilizou como partícipe a figura do engenheiro, em geral, velada por seu saber neutro, mas que era em muito entremeado em sua função sobre o contexto por operações imobiliárias. ${ }^{29}$ Como pontuou D'Elboux, o arranjo amplo de demolições 
era um expediente implícito e um mecanismo para a obtenção de lucro destes atores, incluindo Freire. ${ }^{30} \mathrm{D}^{\prime} E$ lboux confirmou que os arranjos vinham se definindo anteriormente à chegada de Bouvard. ${ }^{31}$ Neste ponto, é significativa a planta que D’Elboux recuperou do plano oficial para o Centro Cívico (Figura 6), mostrando a posição da igreja na área menor do Largo da Sé.

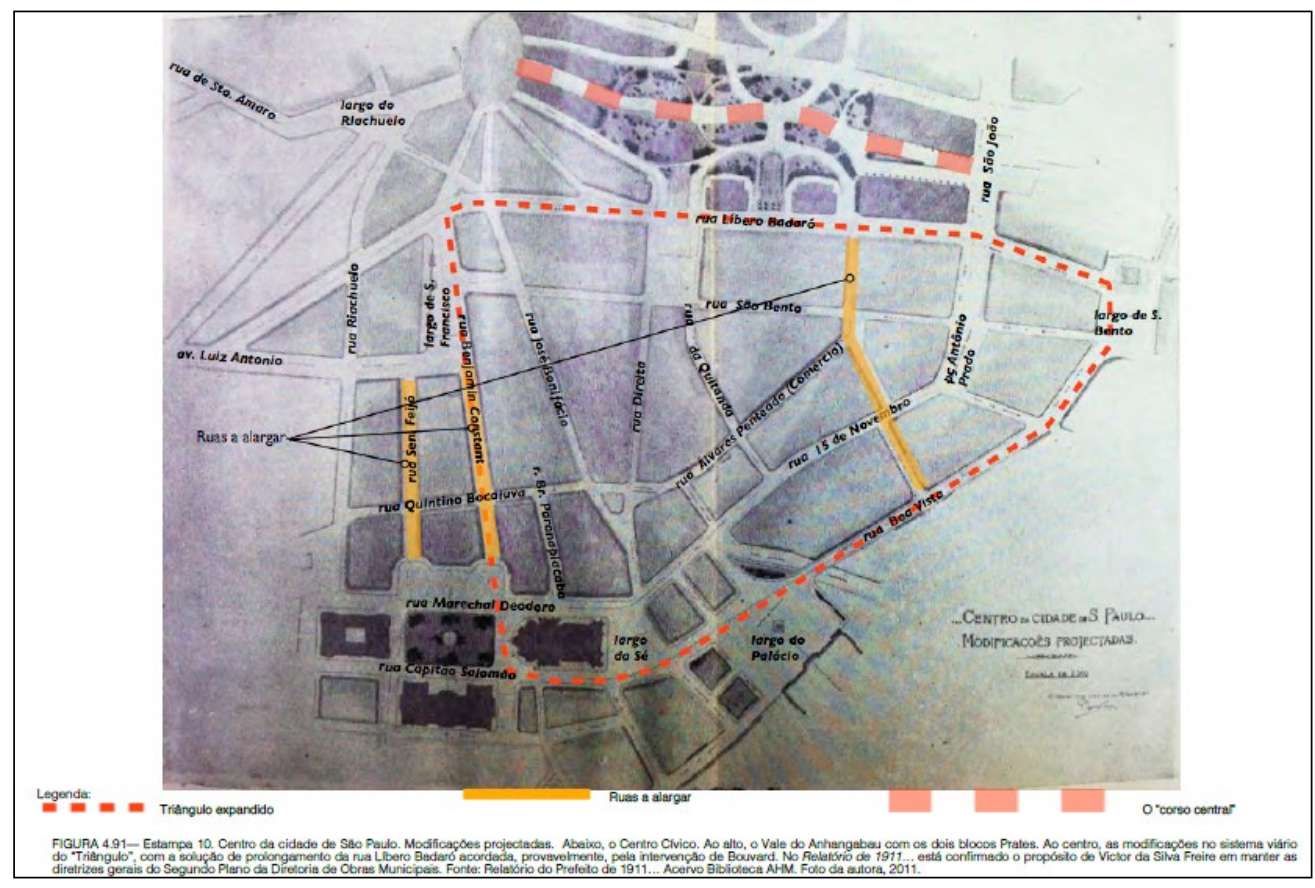

Figura 6 - "Centro da Cidade de S. Paulo - Modificações projetadas - Centro Cívico". Fonte: D'Elboux (2015, p. 547).

arranjo de desapropriações foi sendo montado em esfera municipal pelo prefeito Antonio Prado, quem justificou as primeiras cifras desta operação já no início de 1908. Seu Ofício, apresentado na sessão de 20 de abril de $1908{ }^{32}$ da Câmara Municipal, trazia na costura do processo uma operação financeira de empréstimo externo com o London and Brasilian Bank Limited de Londres, e mediada pelo The Ethelburga Syndicate Limited de Londres, onde era reservada a soma de 1.200:000\$000 descrita como sendo destinada para o "Paço Municipal e as desapropriações". Logo, se reforçava uma arquitetura ainda maior desta rede de relações econômicas que unia "homens poderosos através do Atlântico", 33 aglutinando a presença estrangeira numa trama que Joseph Love (1982) atentou, dos negócios imobiliários na cidade. ${ }^{34} \mathrm{Na}$ contraparte do processo, Dom Duarte não apenas passou por cima da imagem que se pretendia para aquela cidade, no plano material e simbólico quando, inclusive, os pilares de fundação do paço municipal chegaram
30. Ibid. (p. 370).

31. Ibid. (p. 471-472).

32. Ofício. Correio Paulistano, 20 abr. 1908.

33. Love (1982. p. 344).

34. Ibid. (p. 280-281). 
a ser instalados no lugar anexo à Praça João Mendes (Figura 7). Foi o arcebispo também o ator que logrou em articular uma relação conciliatória das esferas públicas urbanas no evento da ereção da Catedral e Praça da Sé na cidade de São Paulo.

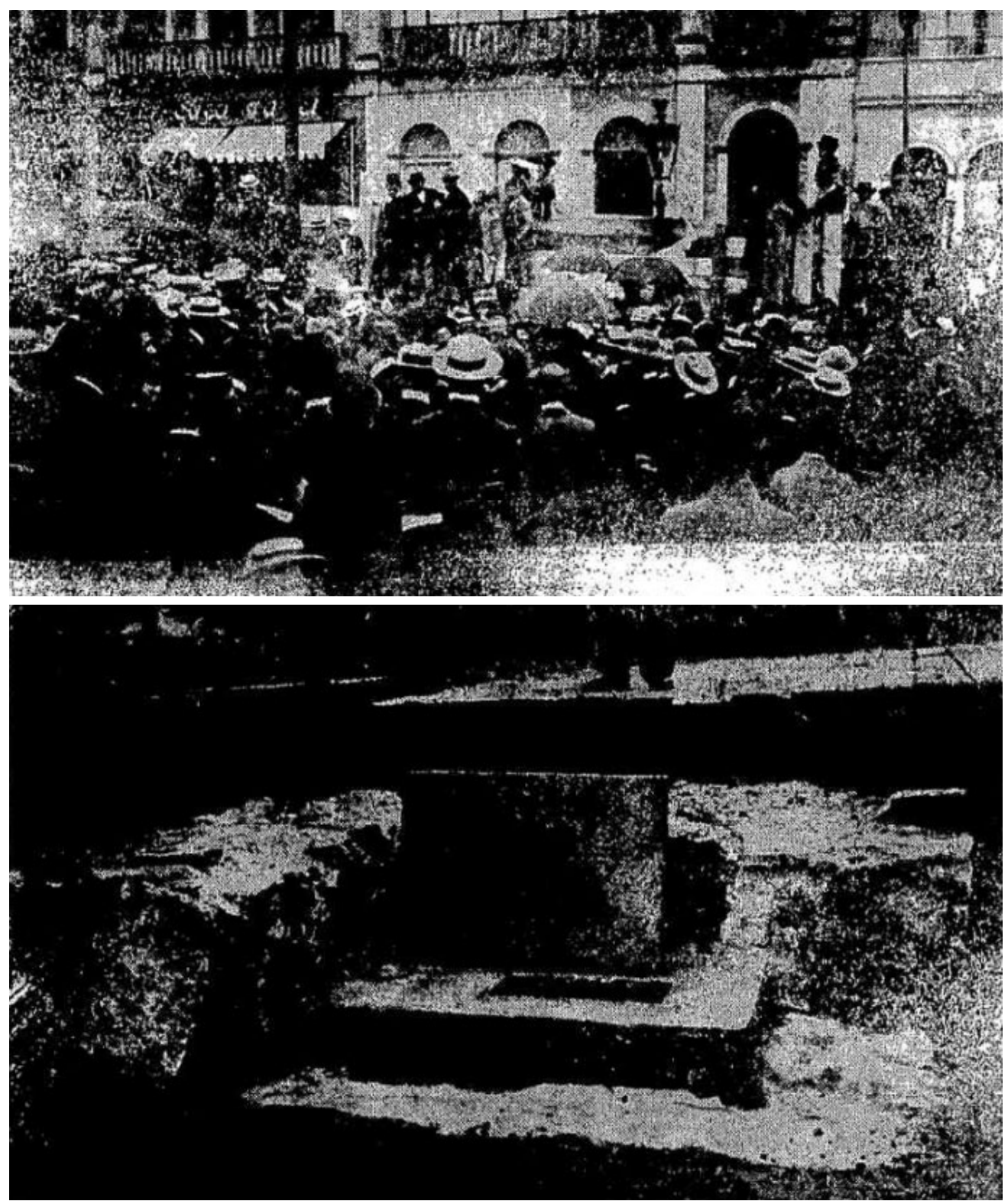

Figura 7 - "I - Um aspecto do ato da colocação da primeira pedra do novo Paço Municipal. II - A pedra fundamental do edifício do Paço Municipal." Fonte: O novo Paço Municipal. O Estado de S. Paulo, 10 jul. 1911. 


\section{OS ACORDOS DEFINITIVOS ENTRE MITRA E ESFERAS PÚBLICAS PARA O DESMONTE (1910-1913)}

Esteve em curso um mascaramento simbólico desta articulação, entre a Mitra e a esfera pública, que de fato acontecia desde 1909, a fim de que fosse construída a catedral em área maior. $\bigcirc$ que levava à necessidade de cifras maiores a serem despendidas pela municipalidade no arranjo de expropriar para demolir. Se revelava então uma tensão onde se forjava um vínculo das propriedades dos atores particulares das quadras. A pasta do mencionado processo, sob a Lei $n^{\circ}$ 1305 de 11 de abril de 1910, anexou como parte de um levantamento detalhado do órgão municipal, três ofícios que foram remetidos à esfera eclesiástica. Neles constavam a relação de nomes dos proprietários particulares, seus respectivos imóveis e valores de locação, e uma coluna de Observações, descrevendo as construções como sobrados velhos, compreendidos entre as ruas Marechal Deodoro, Santa Teresa e Capitão Salomão (Figura 8a, Figura 8b e Figura 8c). Conjuntamente com os ofícios, estava a resposta datilografada e assinada por Antonio Prado, acerca dos termos do acordo passado pelo arcebispo na mediação do seu secretário pela lgreja. $\bigcirc$ prefeito sugeria que

[s]egundo avaliação feita pela Directoria de Obras, que baseou a importancia das desapropriações sobre o valor locativo dos predios interessados pela construcção projectada, as despesas provaveis com as desapropriações devem elevar-se a 449:000\$000. Tendo encarregado o Dr. Procurador deve entender-se com os proprietarios desses predios sobre as quantias por eles exigidas, do officio incluso consta o resultado da sua missão, o qual, como vereis, não offrece base para uma avaliação siquer approximada das quantias a pagar pelos predios em questão, o que fas crer que será necessario recorrer à desapropriação judicial.

Em todo o caso, a despesa não poderá ser feita com os recursos da receita ordinaria, exigindo uma operação de credito. ${ }^{35}$

Mateus Rosada (2011) se debruçou sobre essa postura alavancada pela Igreja no arranjo fundiário urbano, mesmo nas primeiras décadas do século XX. De acordo com ele, uma vez "proprietária na maioria das localidades das terras do perímetro mais central", a igreja "continu[ava] dona d[a]s mesm[a]s, pois seu direito de propriedade [laudêmio] não the [foi] tirado. Mas fic[ava] agora sujeita às possibilidades de desapropriações de seus bens pelo poder público. ${ }^{36}$ Nestes termos, o informe de Antonio Prado deixava claro uma tensão concorrendo como obstáculo à tratativa. Para além daquele montante negociado, uma espécie de lucro indenizatório já naturalizado pelas práticas da igreja (tratado, pois, como
35. Avulso. 25 abr. 1909. Lei $\mathrm{n}^{\circ}$ 1305. Prefeitura do Município de S. Paulo. Diretoria do Protocolo de Arquivo $\mathrm{N}^{\circ}$. Série Legislação. São Paulo: AHM.

36. Rosada (2011, p. 204). 
Figura 8a - Levantamento sobre a área cedida pela Mitra e a área construída de particulares, com as cifras estudadas pela Municipalidade nas desapropriações da área da Sé. Fonte: Lei no 1305. Prefeitura do Município de S. Paulo. Diretoria do Protocolo de Arquivo No. LEG. AHM.

Figura 8b - Levantamento das dimensões e respectivos imóveis dos particulares na área da Sé. Fonte: Lei n 1305. Prefeitura do Município de S. Paulo. Diretoria do Protocolo de Arquivo No. LEG. AHM. "relativamente insignificante", e cogitado sobre imóveis que não eram da propriedade desse ator eclesiástico), concorria um outro circuito das cifras pretendido pelos demais atores, os proprietários particulares em interação com o processo da reconfiguração urbana. Como revelaram os cálculos da Prefeitura pela Diretoria de Obras na figura do técnico Victor Freire, a soma em réis a ser despendida indicava não se tratar de uma área menor.
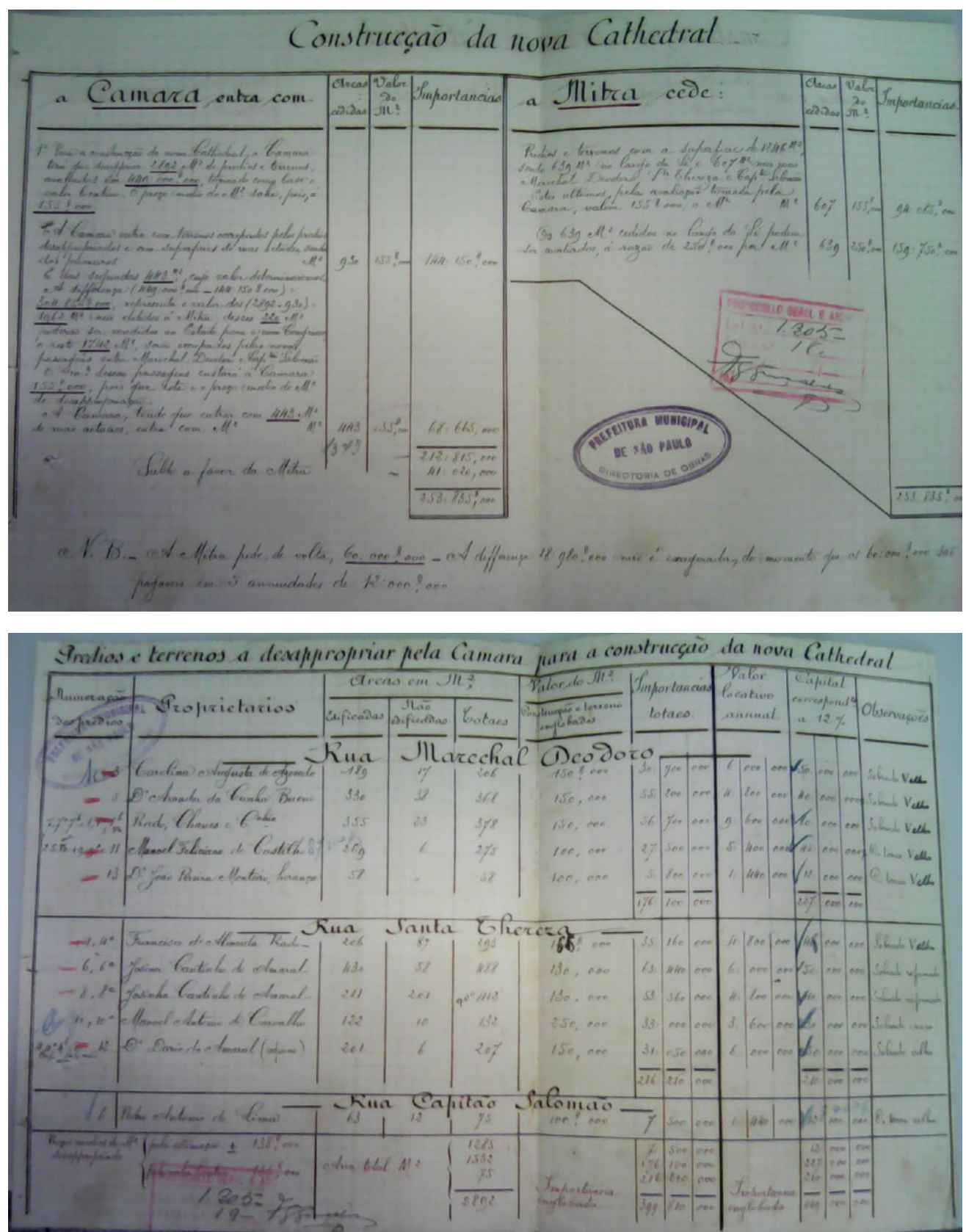


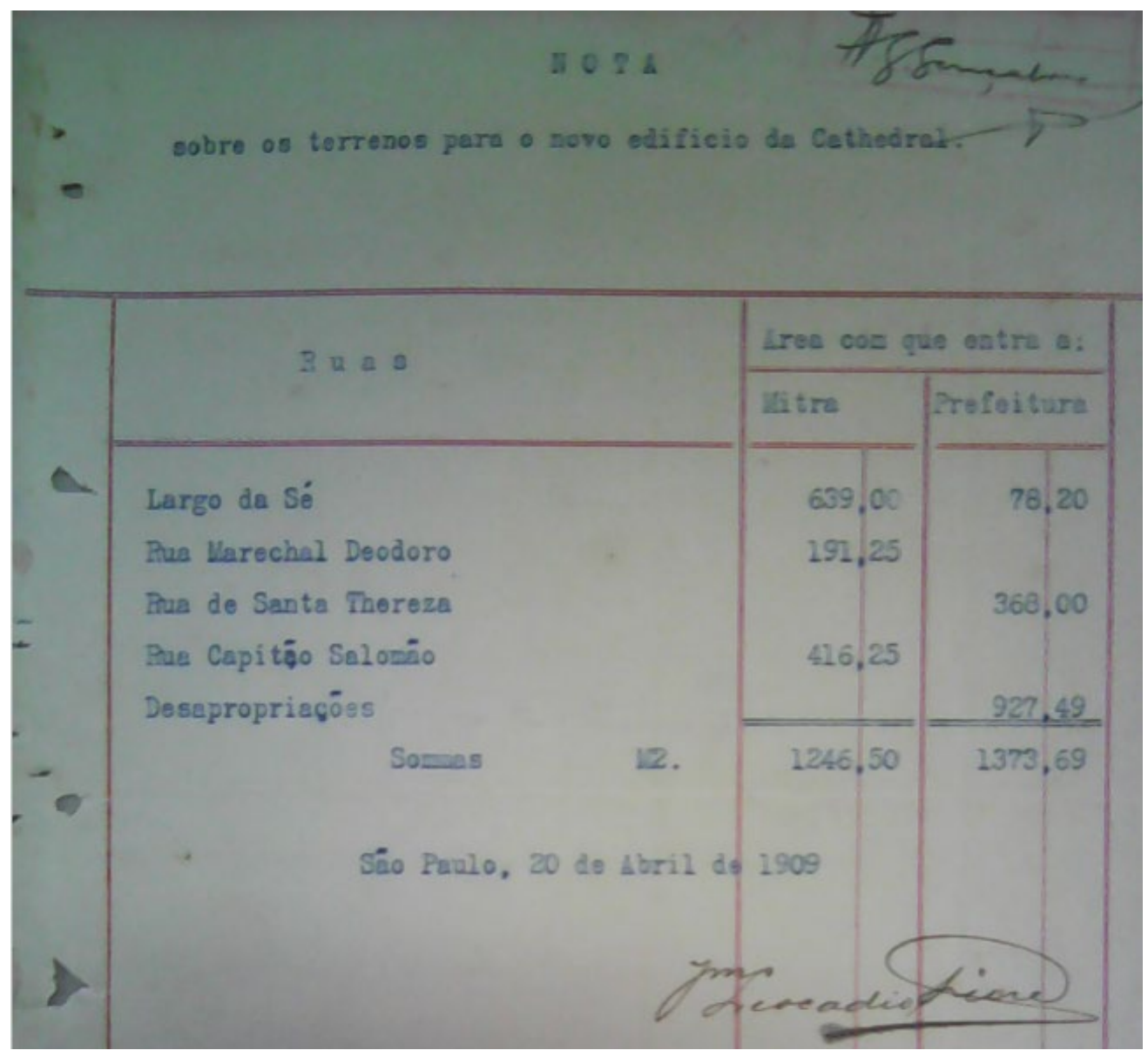

37. Mônica Silveira Brito (2008), em seu trabalho, verificou a posição mediadora do ator institucional, a municipalidade, como não-passiva no acompanhamento deste intenso processo de operação imobiliária, quando parte considerável das terras ou lotes compunham, em realidade, o patrimônio municipal. Afinal, foi também essa esfera da administração pública, ou o círculo da elite dirigente, mais um dos espaços de inserção $d i$ reta ou indiretamente pronunciados na trajetória dos atores proprietários nas áreas demolidas da região da Sé. Cf. Silveira Brito (2008). Como nós verificamos, proprietários como Albuquerque Lins, então governador da Província do Estado; e indiretamente Antonio da Silva Prado, então prefeito, a partir da Chaves e Prado Comp. Portanto, partícipes de uma elite tradicional de longa duração nos processos de impulsionamento material da cidade.

Figura $8 c$ - Nota sobre o total em área somada dos terrenos para o novo edifício da Catedral. Fonte: Lei $n^{\circ}$ 1305. Prefeitura do Município de S. Paulo. Diretoria do Protocolo de Arquivo N. LEG. AHM.

Assim, a lógica da operação da igreja implicava na colaboração da municipalidade, isto é, do prefeito. Para tanto, se valia do instrumento de desapropriação da esfera pública, para transformar o patrimônio particular (laico) em patrimônio municipal, velando da operação a colaboração conjunta do atorparticular (especulador). Sobretudo porque os nomes daqueles que eram proprietários na área-alvo, não figuraram no Livro de Ouro da Catedral, que continha a adesão de doações à Mitra em celebração da obra. A lacuna nos dá um indício da manutenção de um circuito seleto, dominante e homogêneo à frente do arranjo do desmonte. Afinal, os imóveis já vinham ficando em posse da municipalidade, quando boa parte já vinha sendo desapropriada em função da construção, esta que não houve efetivamente naquela área, do Paço Municipal. ${ }^{37}$ Levado à sessão de 2 de abril de 1910 na Câmara Municipal sob o Parecer $n^{\circ}$ 
38. Parecer $\mathrm{n}^{\circ} 16$, da Comissão de Obras. $11^{\circ}$ Sessão Ordinária realizada em 2 abr. 1910.

39. Correio Paulistano, 21 nov. 1910.

40. Arcediago de Capitais. Em que se pede o consentimento do Cabido para a permuta do termo da Catedral. ACMSP. São Paulo: 12 fev. 1913.
16, avaliado pelas Comissões Reunidas de Obras, Justiça e Finanças, que era composta por Goulart Penteado e José Oswald e Azevedo Soares, o acordo em que se chegou reforçava a alegação pela Mitra de que

\begin{abstract}
o terreno situado no Largo da Sé e que vem se aggregar no patrimonio municipal, occupado atualmente pela Cathedral, vale muito mais que aquelle que tem de ser desapropriado pela Camara si se quizer dar o valor real. ${ }^{38}$
\end{abstract}

Segundo esse discurso, o terreno da igreja se superpunha como valendo mais sobre aquele patrimônio laico que também entraria no circuito da desapropriação. Minimizava-se, pois, essa face na operação do desmonte. Por outro lado, estavam as relações do Governador do Estado, nesse arranjo entre as esferas públicas urbanas para o processo do desmonte na área da Sé. Uma vez que era o Estado quem despendia as desapropriações da municipalidade que, por seu turno, agenciava, foi publicizado por nota pelo Correio Paulistano em 21 de novembro daquele mesmo ano, a assinatura de um acordo celebrado entre Dom Duarte e o governo do Estado, representado diretamente pelo Governador Albuquerque Lins, e por Olavo Egydio e Luiz Arthur Varella, em que o "Sr. arcebispo metropolitano desisti[a] não só da acção que intentava contra a Fazenda do Estado, como tambem de qualquer recclamação". ${ }^{39} \bigcirc$ que nos permite entender que, de fato, aquele que costurava o acordo inicialmente era o prefeito Antonio Prado, evitando tensões entre as instituições do Estado e da Municipalidade. Afinal, os manuscritos do Diário Pessoal do ator-arcebispo corroboram para uma políitica conciliadora acontecendo a par e concordância dos lugares partícipes, e realçam novamente o perfil especulador do arcebispo neste processo da reconfiguração espacial da Sé. Um manuscrito de 12 de fevereiro de 1913, endereçado à Dom Duarte pelo Arcediago de Capitais, pedia o seu "consentimento para a permuta do terreno da Cathedral", uma vez quando

[s]ubordinado a um plano geral de melhoramentos da Capital, propõe o Governo do Estado, de acordo com a Municipalidade, ceder à Mitra o local onde actualmente se começou a edificar o Paço Municipal, para ser ahi construída a Cathedral Metropolitana, cuja fachada principal dará para o Largo da Sé ampliado e embellezado. É evidente a magnificencia do projeto que, dando á nossa Cathedral singular sede, contribue estraordinariamente para o embellezamento da nossa já formosa capital. [...] precisa o Arcebispo que [...] conceda um consentimento para permutar o terreno da Cathedral por isso equivalente no local indicado [...].40 
Em resposta, Dom Duarte reafirmava para a igreja um papel no projeto urbano, pelo que endossava tratar-se de "um projecto magnífico; [e] depois de ter [...] ouvido o parecer da Commissão [...] prestou um consentimento para permutar [...]." ${ }^{41}$ Assim, na sequência das tratativas uma outra peça conciliadora foi lançada, com o aparato da imprensa. $\bigcirc$ Correio Paulistano levava às suas páginas em 16 de fevereiro de 1913 uma espécie de carta-agradecimento de Dom Duarte para o secretário da Agricultura, Paulo de Morais Barros, que mediava o desenrolar do processo na Comissão Executiva de Obras:

tendo ouvido o parecer do Revmo. Cabido e da commissão executiva das obras da Cathedral, deliberou-se acceitar o alvitre, em boa hora lembrado por V. Ex. ${ }^{a}$ em nome do exmo. Sr. Presidente do Estado e de accordo com a exma. Prefeitura, de ser a nova Cathedral construída no local actualmente ocupado pelas obras do Paço Municipal. [...] nossa questão, que tanto interessa à magnificencia da Egreja paulista, como contribue para o prestigio de nosso Estado e embellezamento da nossa capital.

A resolução tomada por s. exc. revma., conjugando os interesses da egreja paulista, [...] com os interesses da capital, na parte respeitante ao seu embellezamento, é mais uma prova a confirmar os sentimentos civicos do ilustre prelado $[\ldots] .{ }^{42}$

\section{AS DESAPROPRIAÇÕES E A PRESENÇA DOS ATORES PARTICULARES NO PROCESSO}

A aproximação do dado desapropriatório como via de análise, implica em lidar com um paradoxo. $\bigcirc$ arranjo dos acordos desapropriatórios contém, no limite, uma unilateralidade. Permite chegar, de fato, à camada detentora de titularidade daquele lugar, os proprietários. Por outro lado, porém, Paulo Garcez Marins (2011) tem alertado sobre o olhar da historiografia que aponta o protagonismo do atorexterno, o estrangeiro, na produção do espaço urbano. Para ele, essa ideia resulta num "empalidecimento da capacidade operativa" das chamadas elites locais, numa condição de "recebedores e consumidores passivos" dos moldes modernos, simplificando o "comportamento propositivo e ativo" desses atores, tanto quanto dos "setores médios e da população pobre ou escrava". ${ }^{43}$ Em tabulação das desapropriações na área-alvo da Sé, arrolamos o circuito dos nomes dos atoresdesapropriados; o sistema de numeração dos imóveis identificados na desapropriação; o ano ou a cronologia do caso a caso para a obra de demolição; os logradouros atingidos e a toponímia evocada e grafada; e por fim, um dado mais raro nas histórias sobre a área em estudo: cada uma das cifras da demolição (Tabela 2).
41. Silva, D. Duarte Leopoldo e. "Consentimento prestado pelo Cabido à consulta de Ex. Revo.". ACMSP. São Paulo, 13 de fevereiro de 1913.

42. Correio Paulistano, 16 fev. 1913.

43. Marins (2011, p. 211). 


\begin{tabular}{|c|c|c|c|c|c|c|}
\hline \multicolumn{7}{|c|}{ Largo da Sé } \\
\hline Lei/Decreto & $\begin{array}{l}N^{\circ} \text { do } \\
\text { imóvel }\end{array}$ & $\begin{array}{l}\text { Modali- } \\
\text { dade }\end{array}$ & Justificativa & Proprietário & Valor & Autoridade \\
\hline $\begin{array}{l}\text { Lei n. } 1409 \text {, } \\
\text { de } 17 \text { de } \\
\text { abril de } \\
1911\end{array}$ & $\begin{array}{l}\text { Igreja de } \\
\text { S. Pedro }\end{array}$ & Permuta & $\begin{array}{l}\text { Alinhamen- } \\
\text { to }\end{array}$ & $\begin{array}{l}\text { Irmandade dos } \\
\text { Clérigos de S. } \\
\text { Pedro }\end{array}$ & 25:000\$000 & Raymundo \\
\hline \multicolumn{7}{|c|}{ Rua Capitão Salomão/Rua da Esperança } \\
\hline Lei/Decreto & $\begin{array}{l}N^{\circ} \text { do } \\
\text { imóvel }\end{array}$ & $\begin{array}{l}\text { Modali- } \\
\text { dade }\end{array}$ & Justificativa & Proprietário & Valor & Autoridade \\
\hline $\begin{array}{l}\text { Lei n. } 1083 \text {, } \\
\text { de } 30 \text { de } \\
\text { abril de } \\
1908\end{array}$ & $\begin{array}{l}36 e \\
36-A\end{array}$ & $\begin{array}{l}\text { Arrema- } \\
\text { tação }\end{array}$ & $\begin{array}{c}\text { Construção } \\
\text { do Paço } \\
\text { Municipal }\end{array}$ & $\begin{array}{l}\text { Agostinho Pinto } \\
\text { de Mendonça }\end{array}$ & $45: 001 \$ 000$ & $\begin{array}{l}\text { Antonio da } \\
\text { Silva Prado } \\
\text { (Prefeito) }\end{array}$ \\
\hline $\begin{array}{l}\text { Lei n. } 1139 \text {, } \\
\text { de } 9 \text { de } \\
\text { outubro de } \\
1908\end{array}$ & 36-A & $\begin{array}{l}\text { Arrema- } \\
\text { tação }\end{array}$ & $\begin{array}{l}\text { Construção } \\
\text { do Paço } \\
\text { Municipal }\end{array}$ & $\begin{array}{l}\text { Agostinho Pinto } \\
\text { de Mendonça }\end{array}$ & $45: 001 \$ 000$ & $\begin{array}{c}\text { Astrubal } \\
\text { Augusto do } \\
\text { Nascimento } \\
\text { (Prefeito) }\end{array}$ \\
\hline $\begin{array}{l}\text { Lei n. } 1142 \\
\text { de } 9 \text { de } \\
\text { outubro de } \\
1908\end{array}$ & $\begin{array}{c}38,40 \mathrm{e} \\
48-\mathrm{A}\end{array}$ & Acordo & $\begin{array}{c}\text { Construção } \\
\text { do Paço } \\
\text { Municipal }\end{array}$ & $\begin{array}{c}\text { Manuel Joaquim } \\
\text { de Albuquerque } \\
\text { Lins (40 e 48); } \\
\text { Henrique Schau- } \\
\text { mann (38) }\end{array}$ & $\begin{array}{c}\text { 19:000\$000 (38); } \\
\text { 130:000\$000 } \\
(40,42,44,46 \text { a } \\
46-C ; 48 \text { a } 48-A)\end{array}$ & $\begin{array}{c}\text { Astrubal } \\
\text { Augusto do } \\
\text { Nascimento } \\
\text { (Prefeito) }\end{array}$ \\
\hline $\begin{array}{l}\text { Lei n. } 1144 \text {, } \\
\text { de } 17 \text { de } \\
\text { outubro de } \\
1908\end{array}$ & $\begin{array}{l}50 \text { e } \\
50-A\end{array}$ & Acordo & $\begin{array}{l}\text { Construção } \\
\text { do Paço } \\
\text { Municipal }\end{array}$ & $\begin{array}{l}\text { Agostinho Pinto } \\
\text { de Mendonça }\end{array}$ & $25: 000 \$ 000$ & $\begin{array}{c}\text { Astrubal } \\
\text { Augusto do } \\
\text { Nascimento } \\
\text { (Prefeito) }\end{array}$ \\
\hline $\begin{array}{c}\text { Decreto } \\
\text { n. } 1716 \\
\text { de } 20 \text { de } \\
\text { março de } \\
1909\end{array}$ & $\begin{array}{c}8,10 \\
12 ; 14 \\
16,18 \\
20,22 \\
24,26 \\
28,30 \\
32,34 \\
34-A\end{array}$ & $\begin{array}{l}\text { Utilidade } \\
\text { pública }\end{array}$ & $\begin{array}{l}\text { Constru- } \\
\text { ção de } \\
\text { Repartições } \\
\text { Públicas }\end{array}$ & $\begin{array}{l}\text { Anna Lourenço } \\
\text { Pimentel (8); } \\
\text { Manoel da } \\
\text { Silva Porto (10, } \\
\text { 12, } 14 \text { e 16); } \\
\text { Luiz Pizotti (22); } \\
\text { Clotilde Xavier } \\
\text { Bueno (1 8-18- } \\
\text { A); Mosteiro } \\
\text { São Bento (20 } \\
\text { e 24); Pulcheria } \\
\text { de Araujo Cintra } \\
\text { (26); Emílio } \\
\text { de Paula Jorge } \\
\text { (28); Antonio } \\
\text { Cardoso Ferrão } \\
\text { (30); Mansuetto } \\
\text { Simonini (32); } \\
\text { Nicolau Padula } \\
\text { (34-34-A) }\end{array}$ & $\begin{array}{c}\text { 12:000 } \$ 000(8) ; \\
6: 000 \$ 000(10) \\
14: 000 \$ 000(12) \\
20: 000 \$ 000(14) \\
\text { e 6:500 } \$ 000 \\
(16) ; 23: 000 \$ 000 \\
(18-18-A) ; \\
17: 000 \$ 000(22) ; \\
17: 000 \$ 000(20) \\
\text { e 13:000\$000 } \\
(24) ; 12: 000 \$ 000 \\
(26) ; 17: 000 \$ 000 \\
(28) 14: 000 \$ 000 \\
(30) ; 45: 000 \$ 000 \\
(34-34-A)\end{array}$ & $\begin{array}{l}\text { M. J. de } \\
\text { Albuquer- } \\
\text { que Lins } \\
\text { (Presidente } \\
\text { da Provín- } \\
\text { cia) }\end{array}$ \\
\hline
\end{tabular}




\begin{tabular}{|c|c|c|c|c|c|c|}
\hline $\begin{array}{l}\text { Lei n. } 1200 \text {, } \\
\text { de } 23 \text { de } \\
\text { abril de } \\
1909\end{array}$ & 6 & $\begin{array}{l}\text { Utilidade } \\
\text { pública }\end{array}$ & $\begin{array}{c}\text { Construção } \\
\text { do Paço } \\
\text { Municipal }\end{array}$ & $\begin{array}{l}\text { Anna Maria } \\
\text { Furlani e outros }\end{array}$ & Não consta & $\begin{array}{c}\text { Antonio da } \\
\text { Silva Prado } \\
\text { (Prefeito) }\end{array}$ \\
\hline $\begin{array}{l}\text { Lei n. } 1305 \text {, } \\
\text { de } 11 \text { de } \\
\text { abril de } \\
1910\end{array}$ & 6 & $\begin{array}{l}\text { Utilidade } \\
\text { pública }\end{array}$ & $\begin{array}{l}\text { Contrução } \\
\text { da nova } \\
\text { catedral }\end{array}$ & $\begin{array}{c}\text { Antonio de Lima } \\
\text { Prado }\end{array}$ & Não consta & $\begin{array}{c}\text { Antonio da } \\
\text { Silva Prado } \\
\text { (Prefeito) }\end{array}$ \\
\hline $\begin{array}{c}\text { Lei n. } 1338 \text {, } \\
\text { de } 27 \text { de } \\
\text { junho de } \\
1910\end{array}$ & 6 & Acordo & $\begin{array}{l}\text { Contrução } \\
\text { da nova } \\
\text { catedral }\end{array}$ & $\begin{array}{l}\text { Marcolino Cruz } \\
\text { do Nascimento }\end{array}$ & 7:000\$000 & $\begin{array}{c}\text { Astrubal } \\
\text { Augusto do } \\
\text { Nascimento } \\
\text { (Prefeito) }\end{array}$ \\
\hline $\begin{array}{l}\text { Lei n. } 1625 \text {, } \\
\text { de } 28 \text { de } \\
\text { novembro } \\
\text { de } 1912\end{array}$ & 11 & $\begin{array}{l}\text { Acordo } \\
\text { (verba } \\
\text { "Indeni- } \\
\text { zações") }\end{array}$ & $\begin{array}{c}\text { Formação } \\
\text { de uma } \\
\text { praça }\end{array}$ & Leonora Druker & $650 \$ 000$ & $\begin{array}{l}\text { Raymundo } \\
\text { Duprat } \\
\text { (Prefeito) }\end{array}$ \\
\hline \multicolumn{7}{|c|}{ Rua Marechal Deodoro/Rua do Imperador/Rua do São Gonçalo } \\
\hline Lei/Decreto & $\begin{array}{l}N^{\circ} \text { do } \\
\text { imóvel }\end{array}$ & $\begin{array}{l}\text { Modali- } \\
\text { dade }\end{array}$ & Justificativa & Proprietário & Valor & Autoridade \\
\hline $\begin{array}{l}\text { Lei n. } 1185 \text {, } \\
\text { de } 1^{\circ} \text { de } \\
\text { fevereiro de } \\
1909\end{array}$ & 33 & Acordo & $\begin{array}{c}\text { Construção } \\
\text { do Paço } \\
\text { Municipal }\end{array}$ & $\begin{array}{l}\text { João Emygdio } \\
\text { Ribeiro }\end{array}$ & $65: 000 \$ 000$ & $\begin{array}{c}\text { Antonio da } \\
\text { Silva Prado } \\
\text { (Prefeito) }\end{array}$ \\
\hline $\begin{array}{l}\text { Decreto } \\
\text { n. } 1716 \\
\text { de } 20 \text { de } \\
\text { março de } \\
1909\end{array}$ & $\begin{array}{l}15,17 \\
19,19- \\
\text { A, 21, } \\
23,25 \\
27 \text { e } 29\end{array}$ & $\begin{array}{l}\text { Utilidade } \\
\text { pública }\end{array}$ & $\begin{array}{l}\text { Constru- } \\
\text { ção de } \\
\text { Repartições } \\
\text { Públicas }\end{array}$ & $\begin{array}{c}\text { Carolina Telles } \\
\text { de Escobar e } \\
\text { Reinaldo Porchat } \\
\text { (19, 19-A, } 21 \text { e } \\
\text { 23); João Evan- } \\
\text { gelista de Sousa } \\
\text { (25 e 27); Silvio } \\
\text { Mori (29) } \\
\end{array}$ & $\begin{array}{c}\text { 45:000\$000 (19, } \\
19-A, 21 \text { e 23) }\end{array}$ & $\begin{array}{l}\text { M. J. de Al- } \\
\text { buquerque } \\
\text { Lins (Gover- } \\
\text { nador) }\end{array}$ \\
\hline $\begin{array}{c}\text { Aviso 676, } \\
\text { de } 01 \text { de } \\
\text { agosto de } \\
1909\end{array}$ & $\begin{array}{c}13,15 e \\
15-A\end{array}$ & $\begin{array}{l}\text { Não } \\
\text { consta }\end{array}$ & $\begin{array}{l}\text { Melhora- } \\
\text { mentos do } \\
\text { Largo da } \\
\text { Sé }\end{array}$ & $\begin{array}{c}\text { Thereza de } \\
\text { Souza Franco } \\
\text { Monteiro }\end{array}$ & $50: 000 \$ 000$ & $\begin{array}{c}\text { Antonio da } \\
\text { Silva Prado } \\
\text { (Prefeito) }\end{array}$ \\
\hline $\begin{array}{l}\text { Lei n. } 1263 \text {, } \\
\text { de } 19 \text { de } \\
\text { novembro } \\
\text { de } 1909\end{array}$ & 31 & Acordo & $\begin{array}{c}\text { Construção } \\
\text { do Paço } \\
\text { Municipal }\end{array}$ & $\begin{array}{l}\text { Venerável Ordem } \\
\text { Terceira de } \\
\text { Nossa Senhora } \\
\text { do Monte do } \\
\text { Carmo }\end{array}$ & $44: 000 \$ 000$ & $\begin{array}{c}\text { Antonio da } \\
\text { Silva Prado } \\
\text { (Prefeito) }\end{array}$ \\
\hline $\begin{array}{l}\text { Lei n. } 1305 \text {, } \\
\text { de } 11 \text { de } \\
\text { abril de } \\
1910\end{array}$ & $\begin{array}{c}3,5,7 \mathrm{e} \\
13\end{array}$ & $\begin{array}{l}\text { Utilidade } \\
\text { pública }\end{array}$ & $\begin{array}{l}\text { Construção } \\
\text { da nova } \\
\text { Catedral }\end{array}$ & Mitra de S. Paulo & $272: 815 \$ 000$ & $\begin{array}{c}\text { Antonio da } \\
\text { Silva Prado } \\
\text { (Prefeito) }\end{array}$ \\
\hline
\end{tabular}




\begin{tabular}{|c|c|c|c|c|c|c|}
\hline $\begin{array}{c}\text { Lei n. } 1327 \text {, } \\
\text { de } 1^{\circ} \text { de } \\
\text { junho de } \\
1910\end{array}$ & 35 & Acordo & $\begin{array}{c}\text { Construção } \\
\text { do Paço } \\
\text { Municipal }\end{array}$ & $\begin{array}{c}\text { João Baptista de } \\
\text { M. Vieira }\end{array}$ & 28:000\$000 & $\begin{array}{c}\text { Astrubal } \\
\text { Augusto do } \\
\text { Nascimento } \\
\text { (Prefeito) }\end{array}$ \\
\hline $\begin{array}{c}\text { Lei n. } 1338 \text {, } \\
\text { de } 17 \text { de } \\
\text { julho de } \\
1910\end{array}$ & 3 & Acordo & $\begin{array}{c}\text { Construção } \\
\text { do Paço } \\
\text { Municipal }\end{array}$ & Clóvis Glycerio & $50: 000 \$ 000$ & $\begin{array}{c}\text { Astrubal } \\
\text { Augusto do } \\
\text { Nascimento } \\
\text { (Prefeito) }\end{array}$ \\
\hline $\begin{array}{l}\text { Lei n. } 1374 \text {, } \\
\text { de } 7 \text { de } \\
\text { fevereiro de } \\
1911\end{array}$ & $\begin{array}{c}\text { 5, 9, } \\
9-A, 11 \text { e } \\
13\end{array}$ & $\begin{array}{c}\text { Com- } \\
\text { pra ou } \\
\text { Desapro- } \\
\text { priação }\end{array}$ & $\begin{array}{c}\text { Aplicação } \\
\text { da Lei } \\
\text { n.1305, de } \\
11 \text { de abril } \\
\text { de } 1910\end{array}$ & $\begin{array}{c}\text { Manuel Feliciano } \\
\text { de Castilho (9, } \\
\text { 9-A e 9-B) }\end{array}$ & Não consta & $\begin{array}{l}\text { Raymundo } \\
\text { Duprat } \\
\text { (Prefeito) }\end{array}$ \\
\hline $\begin{array}{c}\text { Lei n. } 1387, \\
\text { de } 25 \text { de } \\
\text { fevereiro de } \\
1911\end{array}$ & 7 e $7-A$ & Compra & $\begin{array}{c}\text { Aplicação } \\
\text { da Lei } \\
\text { n.1305, de } \\
11 \text { de abril } \\
\text { de } 1910\end{array}$ & $\begin{array}{c}\text { Prado Chaves e } \\
\text { Comp. }\end{array}$ & $110: 000 \$ 000$ & $\begin{array}{l}\text { Raymundo } \\
\text { Duprat } \\
\text { (Prefeito) }\end{array}$ \\
\hline $\begin{array}{c}\text { Lei n. } 1444 \text {, } \\
\text { de } 12 \text { de } \\
\text { agosto de } \\
1911\end{array}$ & $\begin{array}{c}\text { 9-A, 9-B, } \\
11 \mathrm{e} \\
11-\mathrm{A}\end{array}$ & $\begin{array}{c}\text { Acordo } \\
\text { (verba } \\
\text { Desapro- } \\
\text { priações) } \\
\end{array}$ & $\begin{array}{c}\text { Formação } \\
\text { de uma } \\
\text { praça }\end{array}$ & $\begin{array}{c}\text { Manuel Feliciano } \\
\text { de Castilho }\end{array}$ & $87: 500 \$ 000$ & $\begin{array}{l}\text { Raymundo } \\
\text { Duprat } \\
\text { (Prefeito) }\end{array}$ \\
\hline $\begin{array}{l}\text { Lei n. } 1446, \\
\text { de } 29 \text { de } \\
\text { agosto de } \\
1911\end{array}$ & 5 & $\begin{array}{l}\text { Acordo } \\
\text { (verba } \\
\text { Desapro- } \\
\text { priações) }\end{array}$ & $\begin{array}{c}\text { Alinhamen- } \\
\text { to }\end{array}$ & $\begin{array}{l}\text { Amador da } \\
\text { Cunha Bueno }\end{array}$ & $\begin{array}{l}550 \$ 000 / \\
160: 000 \$ 00\end{array}$ & $\begin{array}{c}\text { Raymundo } \\
\text { Duprat } \\
\text { (Prefeito) }\end{array}$ \\
\hline \multicolumn{7}{|c|}{ Rua Santa Thereza/Rua Santa Theresa/ Rua Santa Teresa } \\
\hline Lei/Decreto & $\begin{array}{l}N^{\circ} \text { do } \\
\text { imóvel }\end{array}$ & $\begin{array}{c}\text { Modali- } \\
\text { dade }\end{array}$ & Justificativa & Proprietário & Valor & Autoridade \\
\hline $\begin{array}{l}\text { Lei n. } 1265 \text {, } \\
\text { de } 22 \text { de } \\
\text { novembro } \\
\text { de } 1909 \\
\end{array}$ & $\begin{array}{l}10 \text { e } \\
10-A\end{array}$ & $\begin{array}{l}\text { Arrema- } \\
\text { tação }\end{array}$ & $\begin{array}{c}\text { Alinhamen- } \\
\text { to }\end{array}$ & $\begin{array}{c}\text { Manuel Antonio } \\
\text { de Carvalho }\end{array}$ & 30: $100 \$ 000$ & $\begin{array}{l}\text { Antonio da } \\
\text { Silva Prado } \\
\text { (Prefeito) }\end{array}$ \\
\hline $\begin{array}{l}\text { Lei n. } 1305 \text {, } \\
\text { de } 11 \text { de } \\
\text { abril de } \\
1910\end{array}$ & $\begin{array}{c}4 \text { a } 8-A e \\
12\end{array}$ & Permuta & $\begin{array}{l}\text { Construção } \\
\text { da nova } \\
\text { Catedral }\end{array}$ & Mitra de S. Paulo & $272: 815 \$ 000$ & $\begin{array}{l}\text { Antonio da } \\
\text { Silva Prado } \\
\text { (Prefeito) }\end{array}$ \\
\hline $\begin{array}{c}\text { Lei n. 1391, } \\
\text { de } 7 \text { de } \\
\text { março de } \\
1911\end{array}$ & 4 e $4-A$ & Acordo & $\begin{array}{l}\text { Aplicação } \\
\text { da Lei } \\
\text { n. } 1305 \text {, de } \\
11 \text { de abril } \\
\text { de } 1910\end{array}$ & $\begin{array}{c}\text { Fco. Almeida } \\
\text { Prado [Francisco } \\
\text { Almeida Prado?] }\end{array}$ & 48:000\$000 & $\begin{array}{l}\text { Raymundo } \\
\text { Duprat } \\
\text { (Prefeito) }\end{array}$ \\
\hline
\end{tabular}




\begin{tabular}{|c|c|c|c|c|c|c|}
\hline $\begin{array}{c}\text { Lei n.1444, } \\
\text { de } 12 \text { de } \\
\text { agosto de } \\
1911\end{array}$ & 2 & $\begin{array}{c}\text { Acordo } \\
\text { (verba } \\
\text { Desapro- } \\
\text { priações) }\end{array}$ & $\begin{array}{c}\text { Formação } \\
\text { de uma } \\
\text { praça }\end{array}$ & $\begin{array}{c}\text { Manuel Feliciano } \\
\text { de Castilho }\end{array}$ & $87: 000 \$ 000$ & $\begin{array}{l}\text { Raymundo } \\
\text { Duprat } \\
\text { (Prefeito) }\end{array}$ \\
\hline $\begin{array}{l}\text { Lei n.1418, } \\
\text { de } 5 \text { de } \\
\text { maio de } \\
1911\end{array}$ & 12 & Acordo & $\begin{array}{c}\text { Aplicação } \\
\text { da Lei } \\
\text { n. } 1305 \text {, de } \\
11 \text { de abril } \\
\text { de } 1910\end{array}$ & $\begin{array}{c}\text { Bruno Bresse } \\
\text { Monteiro }\end{array}$ & $60: 000 \$ 000$ & $\begin{array}{l}\text { Raymundo } \\
\text { Duprat } \\
\text { (Prefeito) }\end{array}$ \\
\hline $\begin{array}{l}\text { Lei n. } 1438 \text {, } \\
\text { de } 20 \text { de } \\
\text { julho de } \\
1911\end{array}$ & $\begin{array}{c}\text { 6, 6-A, } 8 \\
\text { e 8-A }\end{array}$ & Compra & $\begin{array}{c}\text { Formação } \\
\text { de uma } \\
\text { praça }\end{array}$ & $\begin{array}{c}\text { Josina do Nasci- } \\
\text { mento Coutinho } \\
\text { A. Rocha }\end{array}$ & 190:000\$000 & $\begin{array}{l}\text { Raymundo } \\
\text { Duprat } \\
\text { (Prefeito) }\end{array}$ \\
\hline \multicolumn{7}{|c|}{ Travessa da Esperança } \\
\hline Lei/Decreto & $\begin{array}{l}\mathrm{N}^{\circ} \text { do } \\
\text { imóvel }\end{array}$ & $\begin{array}{l}\text { Modali- } \\
\text { dade }\end{array}$ & Justificativa & Proprietário & Valor & Autoridade \\
\hline $\begin{array}{c}\text { Lei n. } 1189 \\
\text { de } 18 \text { de } \\
\text { fevereiro de } \\
1909\end{array}$ & 6 & $\begin{array}{l}\text { Utilidade } \\
\text { pública }\end{array}$ & Não consta & Não consta & Não consta & Não consta \\
\hline $\begin{array}{l}\text { Decreto } \\
\text { n. } 1716, \\
\text { de } 20 \text { de } \\
\text { março de } \\
1909\end{array}$ & $\begin{array}{c}1,3,5 \\
e^{7}\end{array}$ & $\begin{array}{l}\text { Utilidade } \\
\text { pública }\end{array}$ & $\begin{array}{l}\text { Construção } \\
\text { de edificios } \\
\text { destinados } \\
\text { a Repar- } \\
\text { tições } \\
\text { Públicas } \\
\end{array}$ & Não consta & $17: 300 \$ 000(1)$ & $\begin{array}{l}\text { M. J. de Al- } \\
\text { buquerque } \\
\text { Lins (Gover- } \\
\text { nador) }\end{array}$ \\
\hline $\begin{array}{c}\text { Lei n. } 1209 \text {, } \\
\text { de } 24 \text { de } \\
\text { abril de } \\
1909\end{array}$ & 6 e 8 & $\begin{array}{l}\text { Utilidade } \\
\text { pública }\end{array}$ & $\begin{array}{l}\text { Construção } \\
\text { do Paço } \\
\text { Municipal }\end{array}$ & $\begin{array}{c}\text { Zenze Verona } \\
\text { (6): Antonio Rego } \\
\text { Veiras (8) }\end{array}$ & $\begin{array}{c}\text { 3:092\$000 } \\
\text { [6: } 184 \$ 000 \text { sendo } \\
\text { desapropriação } \\
\text { judicial, segundo } \bigcirc \\
\text { Estado de S. Paulo] }\end{array}$ & $\begin{array}{c}\text { Antonio da } \\
\text { Silva Prado } \\
\text { (Prefeito) }\end{array}$ \\
\hline $\begin{array}{l}\text { Lei n. } 1336 \text {, } \\
\text { de } 21 \text { de } \\
\text { julho de } \\
1910\end{array}$ & 6 & $\begin{array}{l}\text { Indeniza- } \\
\text { ção }\end{array}$ & Não consta & $\begin{array}{l}\text { Genesio Braulio } \\
\text { Rodrigues, Anto- } \\
\text { nia Benedicta de } \\
\text { Toledo Santos e } \\
\text { Adelina Amelung } \\
\text { de Toledo }\end{array}$ & $1: 373 \$ 000$ & $\begin{array}{c}\text { Astrubal } \\
\text { Augusto do } \\
\text { Nascimento } \\
\text { (Prefeito) }\end{array}$ \\
\hline
\end{tabular}

Tabela 2 - Desapropriações no Perímetro da Sé (1910). Fonte:Conjunto de Plantas-Selos, datável de 19081911 . Departamento de Desapropriações - DESAP / PIDE-SIDE. 
44. Morse (1954 apud Cardoso de Mello, op. cit.).

45. Ibid. (p. 130, 139).
A tabulação evidencia o dado da existência de um circuito de particulares, que possuíam os imóveis conformadores das quadras no entorno do Largo da Sé na sua quase totalidade, nestas duas primeiras décadas do século XX. Por outra parte, a partir do cruzamento dos nomes levantados com o dado dos jornais, temos o perfil social dos indivíduos proprietários (Tabela 3). Partindo destes termos, a posição destes atores proprietários, em grande parte originários dos quadros da elite tradicional, também se constituiu de modo semelhante aos setores médios, isto é, por uma enorme mobilidade, como notou Zélia Cardoso de Mello (1981). No contexto anterior ao século XX, conduziu-se um ingresso capitalista em demanda de uma estrutura agroexportadora complexa da economia do café, que exigia um aperfeiçoamento de redes bancárias, maquinários e ferrovias, concorrendo os papéis, fosse direta ou indiretamente por meio de redes familiares, como diretores ou acionistas em companhias. Estes mesmos atores oriundos da elite de base agrária, figurando como os grandes fazendeiros do Oeste Paulista, agenciando o processo de efervescência do café a partir de 1870, operaram sempre em múltiplas atividades urbanas, não concentrando sua riqueza somente neste aperfeiçoamento para o café. Tratava-se de uma economia de diversificação, na forma como estes atores interagiam com as transformações modernizadoras do capital. Desse modo, chegamos àquilo que evidenciou Cardoso de Mello (198 1), de que estes atores concentravam a maior parte de suas riquezas - estas já aquiescidas no momento anterior ao café, como afirmou Richard Morse (1954), potencializadas por pelo menos um século de lavoura canavieira em épocas coloniais ${ }^{44}$-, em realidade, pelos imóveis e os valores imobiliários. ${ }^{45}$

\begin{tabular}{|c|c|}
\hline \multicolumn{2}{|r|}{ Rua Capitão Salomão } \\
\hline Nome & Ocupação Social \\
\hline Agostinho Pinto de Mendonça & $\begin{array}{c}\text { Ocupou cargo de } 1^{\circ} \text { juiz de paz do distrito de Vila Mariana } \\
\text { ("Correio Paulistano". 22/01/1899); era } 5^{\circ} \text { subdelegado } \\
\text { do Sul da Sé ("Correio Paulistano". } 11 / 10 / 1904 \text { ) }\end{array}$ \\
\hline Henrique Schaumann & $\begin{array}{l}\text { Representante da Companhia Paulista Importadora de Drogas } \\
\text { ("Correio Paulistano". } 27 / 07 / 1890 \text { ); 'farmacêutico' ("Cor- } \\
\text { reio Paulistano". 21/08/1892); proprietário de fazenda } \\
\text { no Espírito Santo do Pinhal ("O Commercio de S. Paulo. } \\
29 / 01 / 1896 \text { ); ocupou cargo como diretor do Labora- } \\
\text { tório de Análises Clínicas ("O Commercio de S. Paulo. } \\
\text { 09/01/1896); vereador, membro da Comissão de Justiça e } \\
\text { Polícia, e interlocutor junto a Comissão de Higiene e Saúde" } \\
\text { ("Correio Paulistano". 18/12/1892); membro de associação } \\
\text { comercial, ao lado de nomes como Armando Prado e Silva } \\
\text { Telles ("Correio Paulistano". 18-12-1904); Proprietário de lote } \\
\text { no Largo da Sé ("O Commercio de S. Paulo. 14/01/1908) }\end{array}$ \\
\hline
\end{tabular}




\begin{tabular}{|c|c|}
\hline Manuel da Silva Porto & "Coronel" ("Diário Nacional". 29/05/1928) \\
\hline Luiz Pizzoti & $\begin{array}{l}\text { "Capitalista residente no bairro da Mooca" ("Correio Paulista- } \\
\text { no". 20; } 10 / 1914 \text { ); loteador de casas na Mooca, Taguary e } \\
\text { Javry ("A Gazeta". 17/08/1915); "Conhecido industrial" na } \\
\text { capital ("O Combate". 15/09/1922) }\end{array}$ \\
\hline Pulcherio de Araujo Cintra & $\begin{array}{c}\text { Acionista da Companhia Mogiana ("Relatório da Companhia } \\
\text { Mogiana", 1899) }\end{array}$ \\
\hline Emilio de Paula Jorge & $\begin{array}{c}\text { Capitã da milícia da Guarda Nacional ("Correio Paulistano". } \\
\text { 08/04/1904); sócio fundador do Clube da Guarda Nacio- } \\
\text { nal ("Correio Paulistano". 27/09/1904) }\end{array}$ \\
\hline Antonio Cardoso Ferrão & $\begin{array}{l}\text { Negociante de fazendas de seda, lã, linho, algodão, } \\
\text { perfurmaria, modas e armarinho, a varejo, na Rua de São } \\
\text { bento, } 70 \text { ("Indicador de São Paulo - Administrativo, judicial, } \\
\text { industrial, profissional e comercial, } 1878 \text { "); membro do Con- } \\
\text { selho Fiscal da Companhia Cantareira de Esgotos ("Correio } \\
\text { Paulistano". } 21 \text { /04/1981); secretário de Companhia Carris } \\
\text { de Ferro de S. Paulo ("Correio Paulistano". 23/08/1 187); } \\
\text { fornecedor de material de ferro para obras de saneamento } \\
\text { do Estado ("A Nação". 12/09/1897) }\end{array}$ \\
\hline Nicolau Padula & $\begin{array}{c}\text { Proprietário de imóveis na rua da Glória ("O Estado de S. } \\
\text { Paulo". 20/05/1898); negociante, com fábrica de doces } \\
\text { ("Correio Paulistano". 19/06/1926) }\end{array}$ \\
\hline Marcolino Cruz do Nascimento & $\begin{array}{c}\text { Formado na Escola de Comércio "Alvares Penteado" ("Correio } \\
\text { Paulistano". 28/07/1909) } \\
\end{array}$ \\
\hline Leonora Druker & $\begin{array}{l}\text { Viúva de Alberto Eugenio de Moraes, um dos diretores da } \\
\text { Cia. Urbana Predial ("Correio Paulistano". 19/08/1937) }\end{array}$ \\
\hline \multicolumn{2}{|r|}{ Rua Marechal Deodoro } \\
\hline Nome & Ocupação Social \\
\hline João Emygdio Ribeiro & $\begin{array}{l}\text { Acionista incorporador da Companhia Predial de S. Paulo } \\
\text { ("O Mercanti". 07-09-1880); diretor do Banco Provincial } \\
\text { de São Paulo ("Sentinella da Monarchia". 27-10-1 889); } \\
\text { diretor-secretário do Banco Popular de São Paulo ("Sentinella } \\
\text { da Monarchia". } 1 \text { 1-09-1889); acionista incorporador da } \\
\text { Companhia Rural de São Paulo ("Correio Paulistano". 20-03- } \\
\text { 1891); conhecido como abastado e importante industrial } \\
\text { ("Correio Paulistano". 04-04-1902); diretor do Instituto D. } \\
\text { Anna Rosa, beneficiente, com sede em Vila Mariana, tendo } \\
\text { à frente a família Queiroz ("Correi Paulistano". 18-0 1-1905); } \\
\text { dono de negócio litográfico no imóvel desapropriado ("Cor- } \\
\text { reio Paulistano". 14-12-1905); morador na Rua da Liberda- } \\
\text { de, 46|"Correio Paulistano". O 1-09-1912) }\end{array}$ \\
\hline Carolina Telles de Escobar & $\begin{array}{l}\text { Integrava as Exposições Preparatórias da Escola Complemen- } \\
\text { tar Normal, com os chamados trabalhos femininos, ao lado } \\
\text { de nomes como de Antonieta Leite Penteado ("O Commercio } \\
\text { de S. Paulo. 05/06/1908) }\end{array}$ \\
\hline
\end{tabular}




\begin{tabular}{|c|c|}
\hline João Evangelista de Souza & $\begin{array}{c}\text { Capitão e } 2^{\circ} \text { subdelegado da Sé ("O Commercio de S. } \\
\text { Paulo". 10/09/1901) }\end{array}$ \\
\hline Silvio Mori & $\begin{array}{l}\text { Negociante italiano, que situava negócio - aparentemente um } \\
\text { botequim, no n.21 da R. Marechal Deodoro ("Correio Paulis- } \\
\text { tano". 30/05/1904); residia também negócio na rua Mare- } \\
\text { chal Deodoro, } 29 \text { ("O Estado de S. Paulo". 06/02/1906); } \\
\text { frquentador de um circuito cultural de exposições de pintura } \\
\text { italiana contemporânea, ao lado de nomes como Alfredo } \\
\text { Volpi e Annita Malfatti ("O Combate". 03/06/1919) }\end{array}$ \\
\hline Clovis Glycerio & $\begin{array}{c}\text { Formação na Escola Politécnica de S. Paulo ("Correio Pau- } \\
\text { listano". 15/06; 1898); Associado ao Automóvel Club de } \\
\text { S. Paulo, ao lado de nomes como conde Sylvio Penteado } \\
\text { ("Correio Paulistano". 12/05/1908); Engenheiro (civil) da } \\
\text { Companhia Mogyana ("Correio Paulistano". 12/05/1910); } \\
\text { Filho de Francisco Glycerio, membro da Comissão Diretora } \\
\text { do Partido Republicano ("Correio Paulistano". O6/03/1914); } \\
\text { Engenheiro e fiscal do governo federal, junto à Estrada de } \\
\text { Ferro Noroeste do Brasil, em Mato Grosso ("Correio Paulista- } \\
\text { no". 31/12/1914) }\end{array}$ \\
\hline Prado Chaves e Comp. & $\begin{array}{c}\text { Associado o conselheiro Antonio Prado em firma ("Correio } \\
\text { Paulistano". O6/12/191 1); Ramificada em ramo de venda } \\
\text { de veículo de luxo ("Correio Paulistano". 19/07/1913); mo- } \\
\text { nopólio na exportação do café no convênio anglo-brasileiro } \\
\text { ("Correio Paulistano". 26/1 1/1915); monopólio na expor- } \\
\text { tação de café no convênio franco-brasileiro ("O Combate". } \\
\text { 18/07/1918) }\end{array}$ \\
\hline Amador da Cunha Bueno & $\begin{array}{l}\text { Advogado, possuia seu escritório no imóvel desapropriado, } \\
\text { e residia na rua do lpiranga, 159-A ("Correio Paulistano", } \\
\text { 1904); especulava terrenos devolutos no bairro da Mooca } \\
\text { ("Correio Paulistano". 24-04-1912); frequentador do Salão } \\
\text { Germânia, espaço para "família de elevada reputação" no } \\
\text { circuito social ("Correio Paulistano". O5-04-1913) acionista } \\
\text { da Companhia Mogyana, ao lado de nomes como dos } \\
\text { vereadores Antonio Lobo e Augusto Guimarães ("Correio } \\
\text { Paulistano". 29-06-1915) }\end{array}$ \\
\hline \multicolumn{2}{|r|}{ Rua Santa Teresa } \\
\hline Nome & Ocupação Social \\
\hline Francisco de Almeida Prado & $\begin{array}{c}\text { Filho do fazendeiro indsistuba Antonio Leite de Almeida } \\
\text { Prado, e formado na Escola Politécnica de Zurich ("Correio } \\
\text { Paulistano". 30/05/1884); membro da Comissão Diretora } \\
\text { do Partido Republicano ("Correio Paulistano". 12/01/1909); } \\
\text { morador na Avenida Paulista, } 102 \text { ("Correio Paulistano". } \\
04 / 11 \text { / 1909); vice-presidente da Câmara Municipal de } \\
\text { Orlandia ("Correio Paulistano". 23/02/1913); Sócio efetivo } \\
\text { do Jockey-club, ao lado de nomes como Frederico de Souza } \\
\text { Queiroz ("Correio Paulistano". 23/09/1917) }\end{array}$ \\
\hline
\end{tabular}

Tabela 3 - Proprietários desapropriados na área da Sé (1910). Fonte: A Gazeta; A Nação; Correio Paulistano; Diário Nacional; Indicador de S. Paulo - Administrativo, judicial, industrial, profissional e commercial (1878); $\bigcirc$ Combate; $O$ Commercio de S. Paulo; $O$ Mercanti; O Estado de S. Paulo; Relatorio da Companhia Mogyana (1899): Sentinella da Monarchia, datável de 1878-1928. 
Tendo em vista a informação dos selos da planta desapropriatória sobre o cálculo da municipalidade para valores do metro quadrado na área do Centro, ela evidencia o parcelamento de solo existente para a área no começo do século $X X$. De modo a afirmar a tese para uma permanência de longa duração desse mercado imobiliário elitizado na área da Sé, tal como Beatriz Piccolotto Siqueira Bueno (2016) veio destacando. ${ }^{46}$ Assim a planta, vindo a corresponder à operação de desapropriação de todo o quarteirão do miolo da faixa demolida, sendo ela despendida pelo presidente da Província, Albuquerque Lins, no processo originado no Decreto n 1716/1909 (Figura 9).

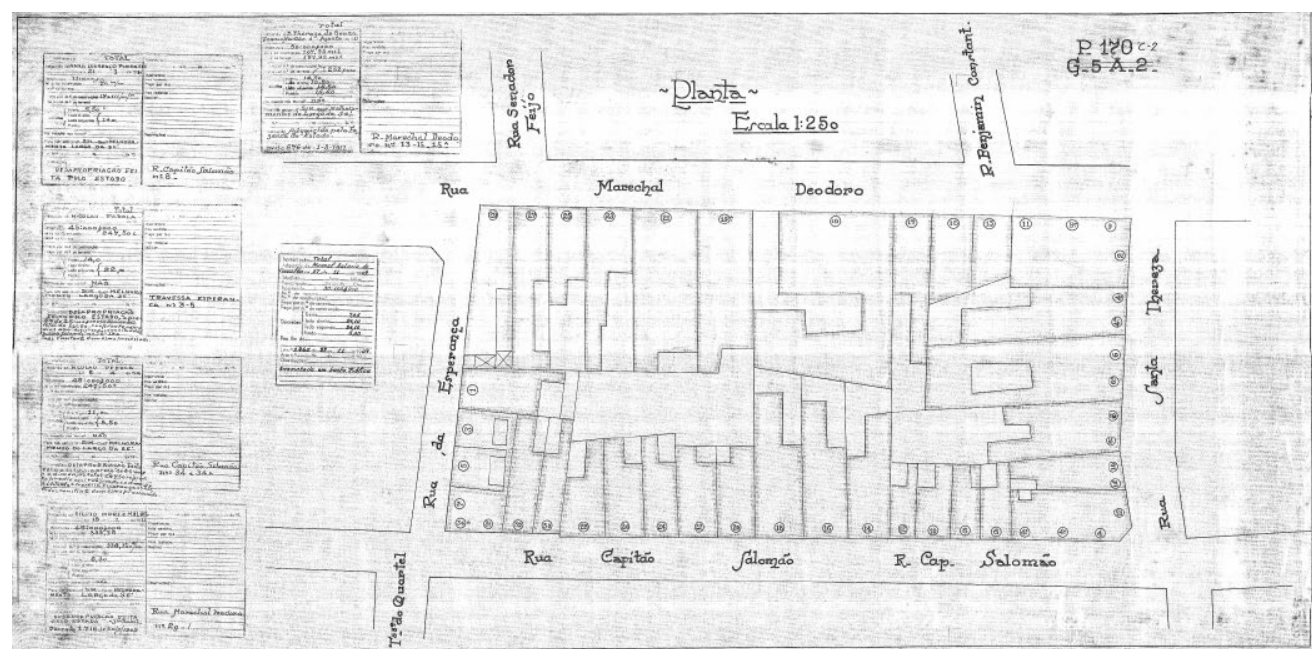

Figura 9 - Levantamento desapropriatório na quadra maior da área demolida para a conformação da Catedral e Praça da Sé. Fonte: Planta 170_C2. DESAP.

Tomando em tela um microexemplo a partir dos selos (Figura 10), o particular Agostinho Pinto de Mendonça, que era também subdelegado do Sul da Sé lTabela 3), recebeu pelos imóveis de ns. 36 e 36-A da Rua Capitão Salomão uma soma vultosa em contos de réis, de 45:001 \$000. O selo descreve um lote de dimensões mínimas, apresentando $180 \mathrm{~m} 86 \mathrm{~cm}^{2}$ de área de construção, por $200 \mathrm{~m} 7 \mathrm{~cm}^{2}$ de área do lote. Além disso, era uma operação de hasta pública (Figura 11), onde o próprio proprietário fixou o valor a ser recebido pelo lote, e levou, com a compra dispendida por esse ator, a municipalidade. Logo, uma lógica inversa ou informal no arranjo, onde a esfera pública apareceria na qualidade de vendedora de terrenos de seu patrimônio municipal, sendo pouco comum ela aparecer neste tipo de relação como compradora do patrimônio particular. ${ }^{47}$ Este proprietário levou também uma outra soma em réis de 25:000\$000 (logo, um valor total de 70:000:000), apenas pelos dois lotes nessa área da Sé, em uma operação desapropriatória pela Lei $n^{\circ}$ $1144 / 1908$ sobre os imóveis de ns. 50 e 50-A. Tais construções abrigavam um
46. Isto nos confirma a tese de uma permanência da concentração do solo urbano desta área por uma minoria abastada - já constituída num período longo, como constatou a historiadora Beatriz Piccolotto Bueno (2016), através do método de espacialização que chamou de sociotopografia - a espacialização desses atores sobre a cartografia física, considerando, afinal, o espaço como uma dimensão da organização de vida dos atores sociais -, por um olhar de processo. Ou seja: uma escala (micro) do dado - cada lote, cada proprietário, cada ocupante, cada uso, cada valor do solo e do metro -, remontados a partir do primeiro imposto predial (colonial) - a Décima Urbana de 1809. Cf. Bueno (2016).

47. Kuvasney (2017, p.168, 438). 
cortiço. Agregando a este dado a informação resgatada na imprensa, em um requerimento trazido em 24 de março de 1885 pelo Correio Paulistano, o proprietário figurava como um agente operando uma lógica de encortiçamento duradoura no processo, situada na passagem do século XIX para o XX (Figura 12).

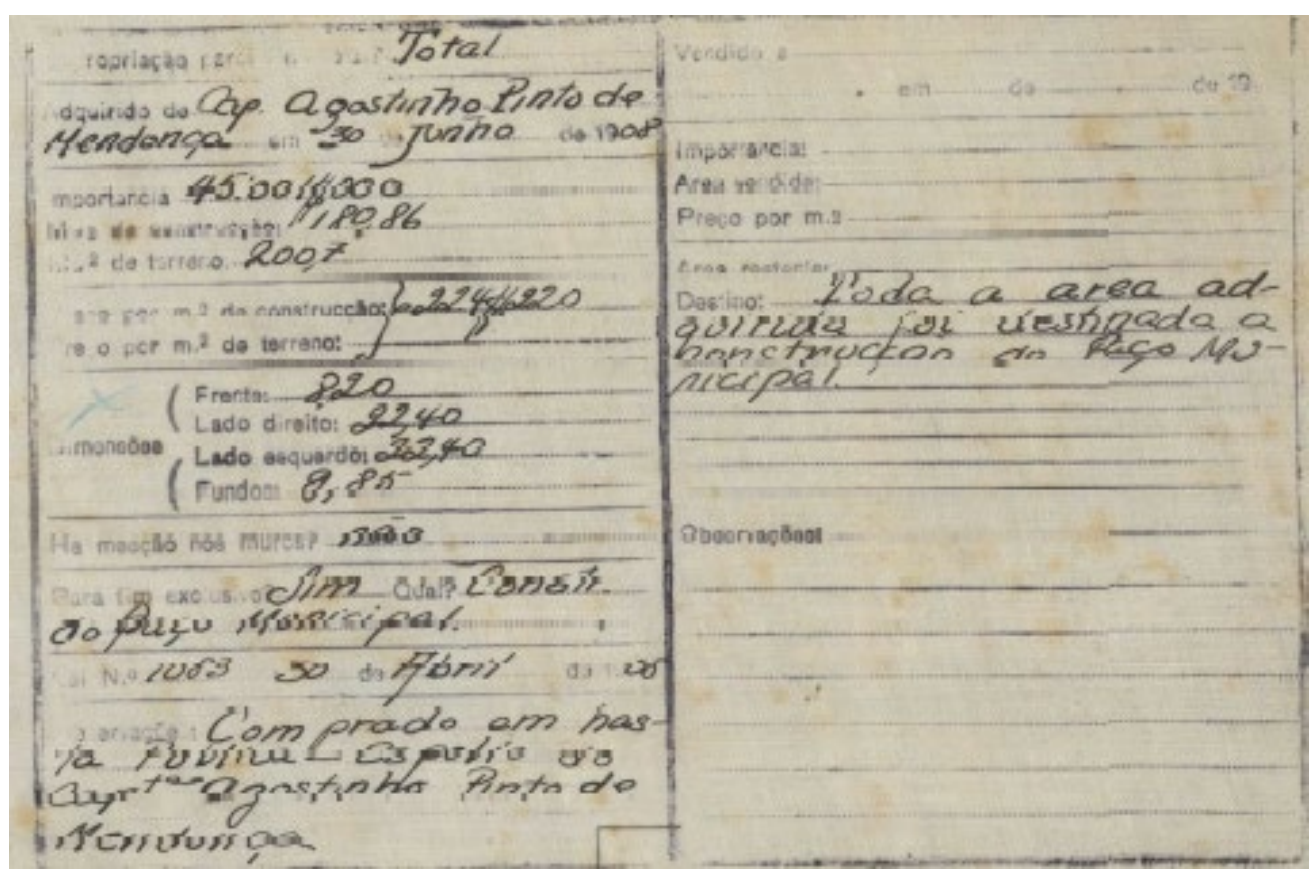

Figura 10 - Selo descritivo da desapropriação dos imóveis de ns. 36 e 36-A da Rua Capitão Salomão, pertencentes ao particular Agostinho Pinto de Mendonça. Fonte: Planta-Lei 1083/1908. 137 B 1. DESAP.

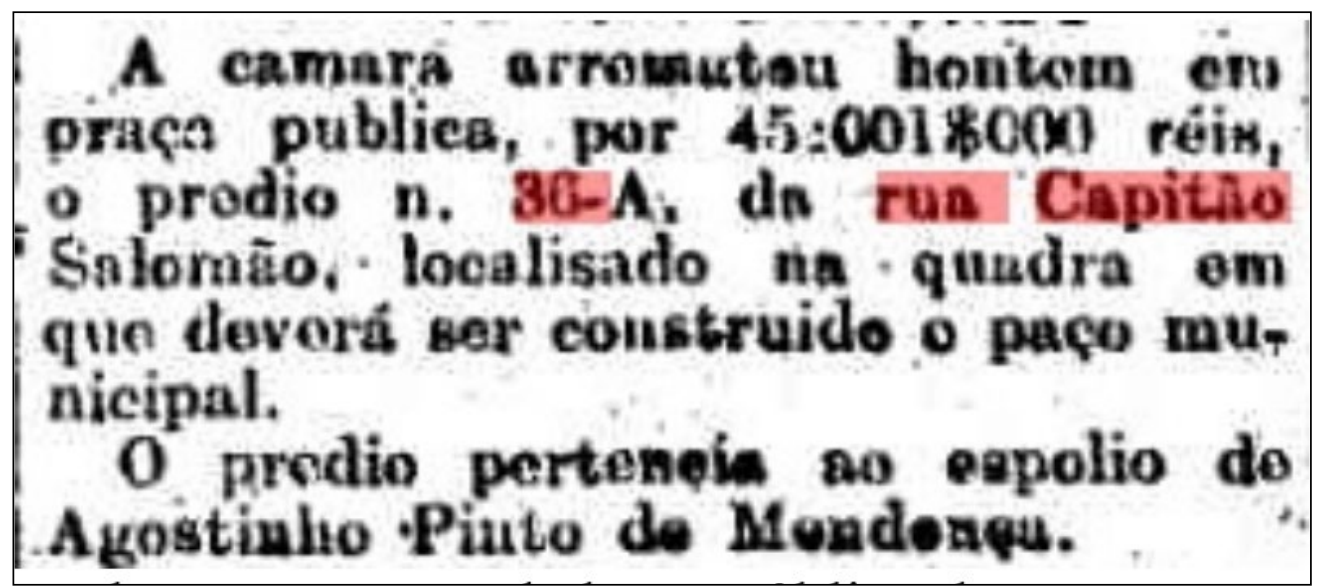

Figura 11 - Publicidade sobre a operação de hasta pública de arrematação do imóvel de $n$. 36-A da Rua Capitão Salomão. Fonte: Prédio Arrematado. O Estado de S. Paulo, [Notas e Informações], 1 jul. 1908. 


\section{De Agostinho Pinto de Mendonça recla- mando contra o imposto de cortiços em que foi collectado, visto como allega não pode- rem ser consideradas como taes as suas pro- priedades.- A' commissão de justiça.}

Figura 12 - Excerto de nota na imprensa, registrando a ocupação de cortiço explorada desde fins do século XIX, pelo proprietário expropriado Agostinho Pinto de Mendonça nos imóveis 50 e 50-A da rua Capitão Salomão, na Sé. Fonte: Requerimentos. Correio Paulistano, 24 mar. 1885.

Um segundo aspecto tomado a partir da tabulação das desapropriações, está no indício de um arranjo sistemático por acordos, com poucas exceções, que obedeceu à tônica amigável, ou, conforme a semântica-padrão dos debates na esfera da Câmara Municipal, a concordância do valor justo. Flávio Eduardo Di Monaco (2007) focou na atuação, pouco explorada, dos poderes urbanos nos arranjos de desapropriação, em termos de suas interações com a feitura da mudança. Ao apropriarem-se de um lugar ativo e antecipatório na construção e reconstrução da cidade, ${ }^{48}$ guardam no seu ideário urbano uma racionalidade avalorística, assim mistificando o arcabouço da legislação urbanística, dentro da qual está o instrumento desapropriatório, tomado exclusivamente em si mesmo, como um "instrumento descompromissado de atuação da vontade estatal" . ${ }^{49}$ Como Di Monaco (2007) bem sustenta, o arranjo desapropriatório paulistano, à maneira de processos transformadores que incorreram sobre um quadro complexo e de fricções, ${ }^{50}$ conformou um indício onde o poder público, assim como seu patrimônio, acabara se confundindo com "o poder e o patrimônio privado dos chefes políticos locais ou regionais". ${ }^{51}$

Dessa forma, a categoria da utilidade pública (Tabela 2) significava outra etiqueta, que, sob o emprego técnico da "desapropriação total de imóveis parcialmente declarados como de utilidade pública", permitia "mais que uma prerrogativa do poder expropriante, um direito conferido ao proprietário, a fim de que não suportasse o ônus de ter seu imóvel desvalorizado em função da desapropriação parcial" . 52 Assim, como defende Di Mônaco (2007), existia uma indústria das desapropriações, favorecendo os proprietários mediante a adesão das esferas municipal e do Estado, que assim legitimava na disciplina (exclusiva) do direito privado, o prejuízo das finanças municipais:
48. Di Monaco (2007, p 205).

49. Ibid. (p. 17).

50. Ibid. (p. 227-228).

51. Ibid. (p. 229).

52. Ibid. (p. 240). 
53. Ibid. (p. 238).

54. A Nova Cathedral. Correio Paulistano. 6 jul. 13.

55. O Estado de S. Paulo, 12 maio 1912.

56. Brefe (1993, p. 2).

57. Assunção; Dantas (2018, p. 11).

58. Mattos (1992, p. 53).

59. Ibid. (p. 38).
Os cofres públicos deveriam financiar o novo, demolir e construir. E foi isto que aconteceu. Os planos de melhoramentos da cidade sempre apontaram como grande vantagem os poucos recursos que eram necessários para que fossem concretizados. [...] Na realização de um plano [a exemplo do de Bouvard] o custo da obra poderia ser amortizado por desapropriações e imóveis envelhecidos que, demolidos, eram reincorporados ao mercado imobiliário como imóveis novos, valorizados. ${ }^{53}$

\section{O CIRCUITO SOCIAL DA OBRA}

O articulista Peixoto Junior, na coluna A Nova Cathedral para o jornal do Correio Paulistano em 6 de julho de 1913, revelava o aspecto contrário à celebração de progresso e melhoramentos até aqui visto: "desapareceu a velha Sé, [...], e em cujo recinto se formaram, [...], os primeiros laços da família paulista". ${ }^{54}$ Já antes, em 12 de maio de $1912^{55}$ uma nota d'O Estado de S. Paulo sinalizava essa ideia sendo socialmente produzida, passando a inventar sobre o espaço urbano um papel para os dois velhos templos. ${ }^{56}$ Todavia, como pontuaram Gabriela Assunção e George Dantas (2018), indicando o "dilema do progresso, entre o novo e o antigo". ${ }^{57} \mathrm{O}$ dilema do progresso, curiosamente, também era manifestado pelo próprio Dom Duarte. O Monsenhor Moraes de Mattos (1992) destacou que

[c]ontava Dom Duarte (Memórias) que depois de determinada a demolição da velha Sé, teve que seguir para Roma, a serviço da Arquidiocese. Voltando de Roma, Dom Duarte passando de carro pela Praça da Sé, não mais viu a Sé dos antepassados bandeirantes. Comprimiu-the a alma e arcaram-the os ombros, sentindo a sua responsabilidade, enorme peso de quem quer demolir, deve fazer coisa melhor. ${ }^{58}$

Assim, Dom Duarte percebia também a "[d]ifícil situação, diante dos [...] que não poderiam conceber a ideia de [...] desaparecer o templo de todos os seus antepassados; de verificar que todo o passado do centro da cidade iria sofrer tão radical modificação". ${ }^{59}$ Esta passagem, que se acha na narrativa levantada por um religioso, é evocada na tradição oral de alguém que conviveu com o arcebispo e carece de cientificidade. Mas ela também demonstra o peso que as decisões de embelezamento, melhoramento, transformações e julgamento pela opinião pública, todavia, despertaram. A demolição destas estruturas urbanas coloniais não foi recebida pacificamente, tampouco em chave unânime. A própria narrativa contida no seio da igreja reforça um caráter controverso. $\bigcirc$ monsenhor Mattos grafou ainda que em "todo o seu desmoronamento, as picaretas no remover 
dos blocos de taipa" foram marcadas por "gritos, lágrimas, protestos por serem sepultados todos os esforços dos antepassados paulistanos". 60

De outra parte, um circuito alternativo da imprensa fomentou uma via dos protestos dentro do processo da reconfiguração da Sé. Nestes termos, se destaca o periódico A Lanterna. Fernando Peres (2005) explicou que o periódico, criado em 1901 por Benjamin Mota a partir da adesão de um grupo de maçons, ${ }^{61}$ comportou uma segunda fase mais ampla a partir de 1909, se formatando como "brecha dos embates da época", cujas pautas anticlericais circulavam por "diferentes atores sociais", na medida em que ideias desde "justiça, trabalho e bem-estar compartilhados" até o socialismo revolucionário "constavam nas tábuas de valores dos grupos [urbanos] presentes em São Paulo na Primeira República, como os maçons, os protestantes, os espíritas, [...], os estudantes, os republicanos (radicais ou descontentes) e os socialistas". ${ }^{62}$ Assim, o periódico era um espaço de construção de uma crítica assídua, dirigida não só aos atores institucionais públicos e eclesiásticos, como às intervenções e demolições que aconteciam no espaço urbano.

Uma nota deste jornal, publicada em 25 de novembro de 1911 , capturava e tencionava a figura do especulador da qual o bispo da catedral de S. Paulo se investiu ao ancorar-se na esfera pública: "trocou casas no quarteirão entre as ruas Capitão Salomão (antiga Esperança), Santa Teresa e Marechal Deodoro", mas não por demandas de "serviço público". Apontava a publicação que era uma operação gigantesca para apenas realizar "o grande sonho da catedral de milhares de contos de reis!". 63 Atentando para o avançar das expropriações para as obras da catedral, que mobilizou a opinião pública fortemente no contexto, o jornal se mostrava em outro artigo dedicado ao assunto, na seção própria A Nova Catedral publicada em 05 de julho de 1913, ainda mais ácido. Prometia "dar aos leitores uma vaga ideia de como se constroem grandes e suntuosas catedrais...", quando "[d]a inutilidade, para o povo, da dispendiosa construção, não é preciso falar", e remontava à "combinação muito lícita" da catedral que "os poderes publicos de S. Paulo vão construir de mão-beijada para o sr. D. Duarte Leopoldo":

\section{$[\ldots]$ grossa pouca-vergonha em que se envolve esse negocio da catedral [...]:}

o governo comprou a vetusta Sé, demoliu-a, vendeu o terreno aplainado ao Arcebispado; afinal, trocou-o por um outro onde estava sendo construído o Paço municipal, com os alicerces já prontos. Resulta que de toda a honesta negociata o sr. Duarte, que tolo não é, abiscoitou algumas centenas de contos de lucro. E depois, convencionou-se que alguns condecos e baronetes dinheirudos, disfarçados em pródigos e sinceros católicos, caíssem também com alguns contecos - grãozinhos de areia atirados no saara do dinheiro necessario para
60. Ibid. (p. 52-53).

61. Peres (2005, p. 1).

62. Ibid. (p. 2-3).

63. A Lanterna, 25 nov. 1911. 
64. "A Nova Cahtedral." $A$ Lanterna, 5 jul. 1913.

65. Posturas (1886, p. 7). a obra projetada -, que eles em breve, interessados como são nas pingues empreitadas da construção, hão de recuperar com as devidas indulgências... e os respectivos juros... ${ }^{64}$

\section{O MERCADO DA DEMOLIÇÃO}

O cruzamento da documentação oficial com a seção de informes da Prefeitura Municipal nas páginas do Correio Paulistano dá a compreensão do processo da demolição, alimentado também em outra rede de colaboradores, que capitaneava um circuito de cifras implicado em um mercado da demolição. Logo, um aparato da destruição já naturalizado nos rearranjos da cidade a um nível da especialização e da ramificação sobre obras de demolição pelas empresas construtoras, já se espacializando nestas primeiras décadas do século XX. O Código de Posturas do Município de São Paulo de 1886 agregava nas bases do processo a lógica que tendia a monopolizar a ação de demolição por particulares, isto é, pelo grupo especulador da cidade. Determinava no Título IV - Dos Edifícios Ruinosos, Escavações e Precipícios, sobre a realização e o custeio da demolição dos imóveis:

Art. 32 - O edifício, muro ou obra de qualquer natureza, que ameaçar ruína, será demolido no todo ou em parte pelo proprietário ou por conta deste, quando e como o Fiscal indicar, precedendo o juízo de dois peritos nomeados pela Câmara e pelo proprietário, ou ambos por ela à revelia deste, correndo todas as despesas por sua conta. O infrator incorrerá na multa de $30 \$ .65$

ator institucional, a municipalidade, uma vez convertendo em lote municipal as construções expropriadas, operou a flexibilização desse arranjo oficial para associar-se a um corpo de atores sociais, particulares, para o serviço de demolição, que era transmutado, porém, em um circuito específico de engenheiros, em via da concorrência pública. $\bigcirc$ Correio Paulistano lançava em 1 de março de 1910 o seguinte Edital da Secretaria Geral da Prefeitura Municipal:

Faço publico que, pelo prazo de oito dias contados da presente data, se acha aberta concorrencia publica para a demolição dos predios ns. 17, 19 e 21 da praça João Mendes; 31 da rua Marechal Deodoro; 6 e 8 da travessa da Esperança; e 36, 36-A, 38, 50 a 52, e 52-A, da rua Capitão Salomão, predios esses de propriedade municipal.

Os proponentes devem offerecer preço englobado pelo material aproveitavel resultante da demolição, como telhas, armação de telhados, portas, janellas, batentes, forros, soalhos, 
canalizações diversas, apparelhos sanitários, etc., demolição essa e remoção dos entulhos que serão feitas por conta dos mesmos proponentes, que caucionarão antes $500 \$ 000$ para garantia da execução das suas propostas, que deverão ser entregues nesta secretaria em carta fechada e lacrada até ao dia 2 de março próximo, ao meio dia, para serem abertas no dia immediato á mesma hora. - Secretaria Geral da Prefeitura do Municipio de S. Paulo, 23 de fevereiro de 1910 - O Diretor Geral. Alvaro Ramos. ${ }^{66}$

Em se tratando de uma operação de demolição de grande monta sobre diversas edificações a um só turno em área de grande extensão na Sé, ela também se constituiu de uma atuação especializada e embutida num circuito rentável para a municipalidade, ao mesmo tempo em que agregou um circuito de cifras com a figura do proponente. Pois, conforme elencado em uma cronologia de microeventos pelo dado do jornal do Correio Paulistano (Figura 13), o tesouro, mesmo perdendo a proposta, despendeu com cada um dos proponentes. Por outro lado, aparece a informação social, o circuito dos nomes dos engenheiros particulares associados à concorrência pública para angariar esła demolição:

05/01/1912 - "Foi apresentada pelo Dr. Oscar Americano, a única proposta para demolição da Igreja de S. Pedro, da Catedral e prédios adjacentes, a qual será aberta amanha ao meio dia."

29/02/1912 - "Serão abertas amanhã, ao meio dia, as propostas dos srs. Francisco Penino, Ignacio Mammano, dr. Oscar Americano e Luiz Mendes Gonçalves, para a demolição do edificio da Sé e prédios adjacentes e da igreja de S. Pedro."

09/03/1912 - "Foi aceita a proposta apresentada em concorrência pública pelo Sr. Luis Mendes Gonçalves para a demolição do edifício da Sé, prédios adjacentes e do edificio da igreja de S. Pedro."

16/04/1912 - "2:000\$000, em restituição, a cada um dos srs. Francisco Penino e Ignacio Mammano, importância caucionada para garantia do contrato para a demolição do edificio da Sé, prédios adjacentes e da igreja de S. Pedro."

Figura 13 - Quadro de escala dos eventos de concorrência pública entre particulares e a municipalidade, para a realização da obra de demolição e venda do material gerado das construções na área-alvo da Sé. Fonte: Correio Paulistano, 1912

\section{CONSIDERAÇÕES FINAIS}

Esse artigo intentou aproximar-se de uma História Urbana no suporte de uma História Social, partindo de um problema de macroescala do processo de remodelações urbanas na cidade de São Paulo, para pensar um problema de microescala do evento da montagem da Praça e Catedral da Sé no alvorecer do 
século XX. Esquadrinhando um recorte espacial na área da Sé, conformado por três quadras e logradouros margeando o Triângulo Histórico, entre o antigo Largo da Sé e a futura Praça João Mendes, mas que foram extintos no processo, tomou-se como problema as demolições urbanas na feitura das relações do público e do privado na cidade, a partir de um itinerário específico das práticas urbanas, ou seja, aquilo que chamamos de antessala, as desapropriações. $\bigcirc$ que nos aproximou dos atores sociais. Uma vez que o apagamento material, um dado conjunto de edificações e atores, por uma série de discursos oriundos dos atores nas elites dirigentes (igreja e estado), foram ocultados no projeto de cidade. Transitamos pelo emaranhado dos discursos, dos acordos, da rede de colaboração, dos pactos, mas também das resistências ou protestos a esse movimento de arruinamento e de disputas de uma memória urbana (do imaginário e do processo social da demolição tratado pelo ator-imprensa). Por fim, das hierarquias dos espaços, e em escala dos vários atores participantes desse processo.

Mobilizando a metodologia de uma História da Não-Preservação, defendida por Fernando Atique (2016) no debate recente dos estudos da cidade de São Paulo, também atentamos para uma outra metodologia que pode ser resumida no termo da sociotopografia, isto é, do olhar no lote a lote, no processo, nas cifras, em cada um dos particulares em chave da espacialização, da cartografia reunindo-os em sobreposição, conforme demonstrou Beatriz Piccolotto Siqueira Bueno (2016). Dessa maneira, o percurso que nós fizemos para chegar nesse mosaico de sujeitos e de imóveis, partiu de uma serialização das fontes primárias, que possibilitaram pistas para pensar a cidade de São Paulo em seu percurso da transformação, não mais compreendida em uma historiografia linear, sublimada e triunfalista do progresso, mas revisando lugares e processos, descortinando instrumentos que possibilitaram a (des)montagem que precedeu o lugar de montagem para esta área central da pauliceia. Analisamos, assim, um projeto de cidade que para se afirmar como moderna, precisou negar as persistências do outro (tempo, materialidade, pessoas), para transformá-la no famigerado laboratório da modernidade discursado pelas elites. 


\title{
REFERENCIAS
}

\author{
FONTES MANUSCRITAS
}

ARCEDIAGO de Capitais. "Em que se pede o consentimento do Cabido para a permuta do termo da Catedral”. ACMSP. São Paulo: 12 de fevereiro de 1913.

Planta 137_B1 - Lei 1083, de 1908. São Paulo: DESAP.

Planta 170_B1 - Lei 1265, de 22/11/1909 (quadra, lote, ficha-selo). São Paulo: DESAP.

Planta - Lei No 1305/1910. Série Legislação. São Paulo: AHM.

Planta 41_C2 e 64_B1 - Lei 1409, de 17/04/1911 (quadra, lote, ficha-selo). São Paulo: DESAP.

"Planta Cadastral e Comercial da Cidade de São Paulo" (1911). Editores: Thomas \& Cia. APESP. Disponível em: <https://bit.ly/30A2POS>. Acesso em: 18 nov. 2018.

SILVA, D. Duarte Leopoldo e. "Consentimento prestado pelo Cabido à consulta de Ex. Revo.". ACMSP. São Paulo, 13 de fevereiro de 1913.

FONTES IMPRESSAS

"Título IV - Dos edificios ruinosos, excavações e precipicios." Código de Posturas do Município de São Paulo. 06 de outubro de 1886. USP-FAU. Disponível em: <https://bit.ly/2DnlWmE>. Acesso em: 04 out 2018.

“Lei n.1305." Prefeitura do Município de S. Paulo. Diretoria do Protocolo de Arquivo No. Série Legislação. São Paulo: AHM. (avulso, folha 1, folha 2, folha 3)

MATTOS, S. M (Monsenhor). A Velha Catedral de S. Paulo. Livro n.2, traço n.38. São Paulo: ACMSP, 1992.

PINTO, Alfredo Moreira, 1847-1903. A Cidade de S. Paulo em 1900: impressões de viagem. Rio de Janeiro: Imprensa Nacional, 1900. Disponível em: $<$ https://bit.ly/2XHppDc $>$. Acesso em: 04 out. 2018. 
AQUINO, Maurício. Modernidade republicana e diocesanização do catolicismo no Brasil: as relações entre Estado e Igreja na Primeira República (1889-1930). Revista Brasileira de História, São Paulo, v. 32, n 63, p. 143-170, 2012. Disponível em: https://bit.ly/2PxRicm. Acesso em: 28 set. 2018.

ASSUNÇÃO, Gabriela Lira; DANTAS, George Ferreira. Demolições, debates e tentativas de preservação: aproximações a partir dos casos de Salvador e Recife (1910-1930). Urbe. Revista Brasileira de Gestão Urbana, 2018. Disponível em: <https://bit.ly/3gF6UH8>. Acesso em: 08 set. 2018.

ATIQUE, Fernando. A midiatização da (não) preservação: reflexões metodológicas sobre sociedade, periodismo e internet a propósito da demolição do Palácio Monroe. Anais do Museu Paulista, v. 24, p. 152, 2016. Disponível em: <https://bit.ly/33EUMC7>. Acesso em: 06 jul. 2017.

ATIQUE, Fernando. De "Casa Manifesto" a "Espaço de Desafetos": os impactos culturais, políticos e urbanos verificados na trajetória do Solar Monjope (Rio, anos 20 - anos 70). Estudos Históricos (Rio de Janeiro), v. 29, p. 213-232, 2016. Disponível em: <https://bit.ly/3ilg7oi>. Acesso em: 06 jul. 2017.

BREFE, Ana Claudia Fonseca. A Cidade Inventada: a pauliceia construída nos relatos memorialistas (1870-1920). (Dissertação de Mestrado). Unicamp-IFCH. 1993. Disponível em: <https://bit.ly/3fEShlC>. Acesso em: 04 mai. 2018.

BRITO, Mônica Silveira. A Participação da Iniciativa Privada na Produção do Espaço Urbano: São Paulo, 1890-1911. São Paulo: FAU-USP, 2008.

BUENO, Beatriz Piccolotto Siqueira. Aspectos do Mercado Imobiliário em Perspectiva Histórica: São Paulo (1809-1950). São Paulo: EDUSP, 2016.

CERASOLI, Josianne. A Grande Cruzada: os engenheiros e as engenharias de poder na Primeira República. IFCH-UNICAMP. (Dissertação de Mestrado). 1998. Disponível em: <https:// bit.ly/3ik0TzV>. Acesso em: 08 dez. 2019.

CERASOLI, Josianne. Modernização no Plural: obras públicas, tensões sociais e cidadania em São Paulo na passagem do século XIX para o XX. (Tese de Doutoramento). IFCH-UNICAMP, 2004.

D'ELBOUX, Roseli M. M. Joseph-Antoine Bouvard no Brasil. Os melhoramentos de São Paulo e a criação da Companhia City: ações interligadas. (Tese de Doutoramento). FAU-USP, 2015. Disponível em: <https://bit.ly/3adobon>. Acesso em: 20 set. 2018. 
DI MONACO, Flávio Eduardo. O Banquete do Leviatã: direito urbanístico e transformações da zona central de São Paulo (1886-1945). (Tese de Doutoramento). FAU-USP, 2007. Disponível em: <https://bit.ly/2DwiNkl>. Acesso em: 27 jun. 2018.

FREHSE, Fraya. Potencialidades do método regressivo-progressivo: pensar a cidade, pensar a história. Tempo Social; Rev. Sociol, São Paulo, v. 13, n. 2, p. 169-184, novembro de 2001. Disponível em: <https://bit.ly/2DKqDXr>. Acesso em: 17 dez. 2019.

KUVASNEY, Eliane. A Representação da Cidade de São Paulo nos Albores do Século XIX: os mapas como operadores na construção da cidade espraiada. (Tese de Doutoramento). FFLCHUSP. 2017. Disponível em: <https://bit.ly/3fCkVE7>. Acesso em: 08 dez. 2019.

LOVE, Joseph. A Locomotiva: São Paulo na Federação Brasileira 1889-1937. São Paulo: Paz Terra, 1982.

MARINS, Paulo César Garcez. Um lugar para as elites: os Campos Elísios de Glette e Nothmann no imaginário urbano de São Paulo. In: LANNA, Anna Lúcia et al. São Paulo, Os Estrangeiros e a Construção das Cidades. São Paulo: Alameda, 2011.

MELLO, Zélia Cardoso de. Metamorfoses da Riqueza - São Paulo, 1845-1895: contribuição ao estudo da passagem da economia mercantil-escravista à economia exportadora capitalista. (Tese de Doutoramento). FEA-USP. 1981.

MIYAZAKI, Elizabeth. Praça da Sé. São Paulo: FAU-USP. 1979.

MORSE, Richard. De Comunidade à Metrópole: biografia de São Paulo. São Paulo: Comissão do IV Centenário da Cidade de São Paulo, Serviço de Comemorações Culturais. 1954.

NOVO, Leonardo. Entre Arte e Técnica: "arquiteturas políticas" na legitimação da profissão no Brasil [1920-1930]. IFCH-Unicamp (Dissertação de Mestrado). 2018. Disponível em: <https:// bit.ly/2PFUcfb>. Acesso em: 08 dez. 2019.

PERES, Fernando. Guerra aos padres: o jornal anticlerical A Lanterna em São Paulo na Primeira República. ANPUH - XXIII Simpósio Nacional de História. Londrina, 2005. Disponível em: $<$ https://bit.ly/3a7gvnz>. Acesso em: 08 dez. 2019.

PERISSINOTO, Renato Monseff. Introdução. Estado e Capital Cafeeiro em São Paulo, 18891930. São Paulo: Fapesp Annablume, 1999. 
ROMANO, Cristina de Toledo. Santa Cecília: uma paróquia na confluência dos interesses da elite paulistana e da igreja católica entre 1895 e 1920. (Tese de doutoramento). FFLCH-USP. 2008. Disponível em: <https://bit.ly/3kn3rzh>. Acesso em: 18 jan. 2019.

ROSADA, Mateus. Sob o Signo da Cruz: Igreja, Estado e secularização (Campinas e Limeira 17741939). (Dissertação de Mestrado). EE-UFSCar. 2011. Disponível em: <https://bit.ly/2PBF1Ul>.

SOUSA, Rebeca Grilo de. Escombros e Vestígios: os debates sobre os arrasamentos nas reformas urbanas das cidades brasileiras (Rio de Janeiro, São Paulo e Recife no início do século XX). UFRN (Dissertação de Mestrado). 2016. Disponível em: <https://bit. ly/3ih6oQ3>. Acesso em: 24 mar. 2018.

THOMPSON, E. P. A formação da classe operária inglesa. A árvore da liberdade. Rio de Janeiro: Paz e Terra, 2004.

THOMPSON, E. P. Costumes em comum: Estudos sobre a cultura popular tradicional. São Paulo: Companhia das Letras, 2005.

SITES

"Archbishop Duarte Leopoldo e Silva." Catholic Heritage. Disponível em: <https://bit. ly/3gGv8kd>. Acesso em: 18 mar. 2018.

Artigo apresentado em: 27/5/2020. Aprovado em: 9/10/2020.

\section{(cc) BY}

